\title{
Working
}

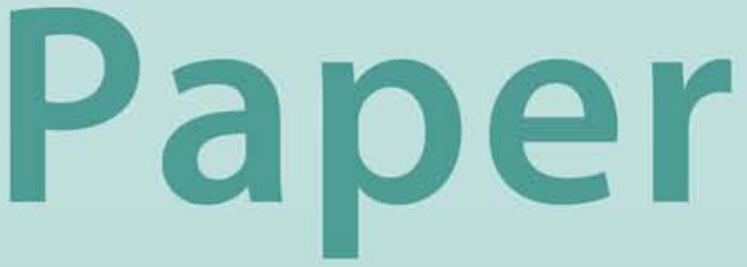




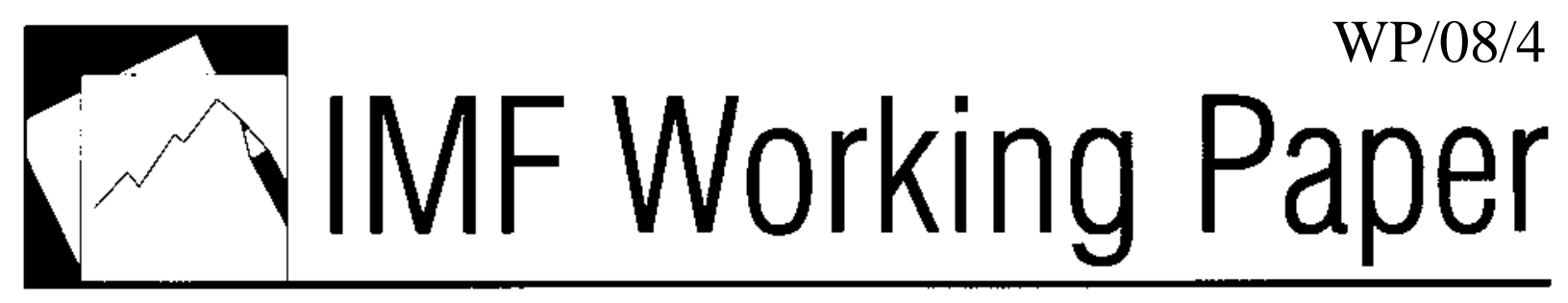

Does Technological Diffusion Explain Australia's Productivity Performance?

Thierry Tressel 


\title{
IMF Working Paper
}

Research Department

\section{Does Technological Diffusion Explain Australia's Productivity Performance?}

\author{
Prepared by Thierry Tressel ${ }^{1}$
}

Authorized for distribution by Masahiko Takeda and Alessandro Prati

January 2008

\begin{abstract}

\section{This Working Paper should not be reported as representing the views of the IMF.}

The views expressed in this Working Paper are those of the author(s) and do not necessarily represent those of the IMF or IMF policy. Working Papers describe research in progress by the author(s) and are published to elicit comments and to further debate.
\end{abstract}

This paper analyzes the impact of product and labor market policies on technological diffusion and multi-factor productivity (MFP) in a panel of industries in 15 OECD countries over the period 1980 to 2003, with a special focus on Australia. We use a simple convergence empirical framework to show that, on average, convergence of MFP within industries across countries has slowed-down in the 1990s. In contrast, Australian industries have significantly caught-up with industry productivity best practices over the past 16 years, and have benefited from the diffusion of Information and Communication Technologies (ICTs). We show that reforms of both the labor and product markets since the early 1990s can explain Australia's productivity performance and adoption of ICTs.

JEL Classification Numbers:D24, J08, J24, K2, L6, L8, L9, O3.

Keywords: Australia, Productivity, Technology Diffusion, Labor Market, Product Market

Author’s E-Mail Address: $\underline{\text { tressel@imf.org }}$

\footnotetext{
${ }^{1}$ The author would like to thank David Coe, Masahiko Takeda, Hali Edison and participants at a seminar at the Australian Treasury during the Article IV consultation of the IMF (June 2007) for useful remarks and suggestions. Manzoor Gill and Jose Romero provided excellent research assistance.
} 
I. Introduction

II. Productivity Performance and Reforms in Australia ............................................. 7

A. Australian Productivity Performance since 1990: Key Facts ..................................

B. The Reform Process in Australia .................................................................

III. Empirical Model and Data Description .........................................................
A. Theory
B. Empirical Specification
C. The Long-Run Impact of Covariates X on MFP and Capital-Labor Ratio Levels ... 12
D. Data Sources and Methodology
E. Growth Accounting
F. Level Accounting.
G. Exchange Rates for International Comparisons

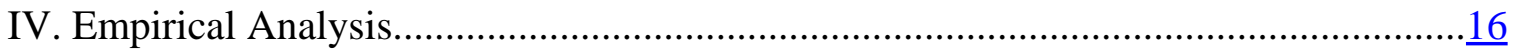

A. A First Look at the Data................................................................................ 16

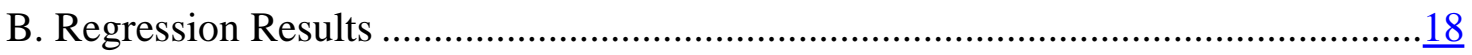

C. Robustness Tests ...................................................................................... 20

D. Do Reforms Explain Australia's Productivity Performance? .................................20

E. Other Determinants of MFP Convergence: the Role of Human Capital and R\&D ..21

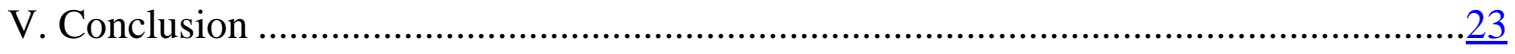

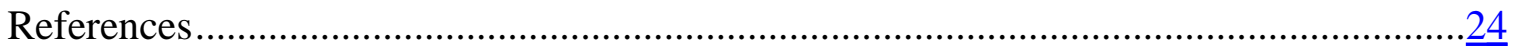

Tables

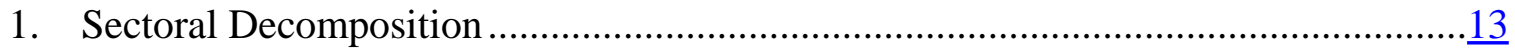

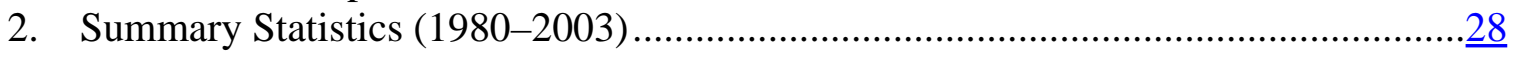

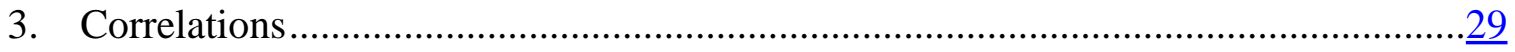

4. Multi-Factor Productivity Leaders ...................................................................

5. Convergence of Australian Industries' Technology Level in a Panel of OECD Countries..........................................................................................

6. Impact of Product Market Regulations of MFP Growth .........................................

7. Impact of Labor Market Institutions on MFP Growth............................................

8. Disentangling the Effects of Product and Labor Market Institutions

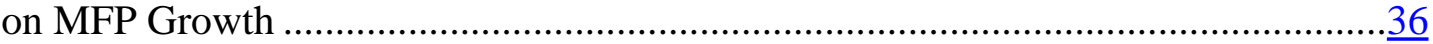

9. Impact of Labor and Product Market Institutions on ICT Capital Deepening ….........

10. Predicted Impact of Product and Labor Market Reforms ...........................................

11. Controlling for Other Determinants of MFP Growth ........................................... 
Figures

1. Australia's Productivity Performance .

2. Investments in Information and Communication Technologies....................................

3. Sectoral Contributions to Real GDP Growth........................................................

4. Employment Protection Legislations in OECD Countries ............................................

5. Product Market Reforms in Australia ....................................................................

6. Australian Industries MFP Levels (relative to U.S.)...............................................

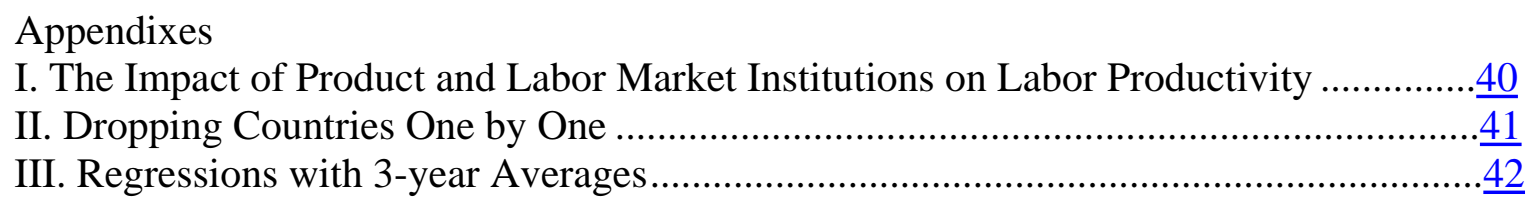




\section{INTRODUCTION}

\section{"Lessons from Apple Co.: not invented here ... and very welcome"} The Economist, June 2007

Since the end of the 1991 recession, Australia has experienced a long lasting economic expansion during which labor productivity has increased by close to 30 percent, almost the same feat as the one realized by the U.S. economy over the same period. ${ }^{2}$ Moreover, the Information and Communication Technology (ICT) revolution, which has been behind the productivity revival in the U.S., seems to have diffused around the globe to Australia as well. ${ }^{3}$ Over the past 16 years, Australia has also undertaken many reforms, in particular of the labor and product markets, and has followed sound and prudent monetary and fiscal policies, which have enhanced the flexibility of the economy and its resilience to shocks.

What explains this success story? The objective of this paper is to look at Australia's productivity performance from the perspective of productivity best practices diffusion across OECD countries. We look at the diffusion of technology from two angles: (i) multi-factor productivity and (ii) the diffusion of ICT capital, and assess the role of policies in fostering diffusion. More specifically, we ask whether Australia's reforms explain the sustained productivity acceleration observed since 1991. More generally, this paper provides new evidence on the interaction between technology diffusion and policies in OECD countries.

We find that product market reforms have a significant and positive impact on multifactor productivity (MFP), in particular in industries that use ICT capital goods more intensively. ${ }^{4}$ However, the magnitude of the estimated impact is not sufficient to explain the productivity acceleration observed in these industries in Australia. Next, we find that labor market flexibility seems to be associated with faster productivity gains in industries that are more human capital intensive. The magnitude of the estimated effect is large. We also find that countries with more flexible labor markets have experienced a faster ICT capital deepening. These results suggest that, in the case of Australia, a combination of labor and product market reforms could have induced productivity gains of the order of magnitude of those observed in the 1990s. Finally, we find that technological diffusion crucially depends on domestic R\&D intensity and human capital, even after controlling for product market and labor market policies, suggesting that a wide range of factors affect the diffusion of technology best practices across OECD countries. ${ }^{5}$

\footnotetext{
${ }^{2}$ Davis and Rahman (2006) and Dolman et al. (2007) provide an overview of Australia’s productivity performance and of its determinants.

${ }^{3}$ See OECD (2003), Parham et al. (2001), Productivity Commission (2004), and Cardarelli (2001a).

${ }^{4}$ In the paper, we will use alternatively multi-factor productivity (MFP) or total factor productivity (TFP) to name Hicks-neutral productivity effects that are not biased in favor of any factor of production.

${ }^{5}$ We use the EU-KLEMS and IGA database of the GGDC, which are the best existing datasets providing information on productivity across OECD countries and at a disaggregated level with a break-down between
} 
A growing literature has tried to identify the factors driving the diffusion of technology within industries across OECD countries. The role of domestic R\&D in innovation and in speeding up the adoption of existing technologies has been emphasized by Griffith et al. (2004), and Cameron et al. (2005). Acharya and Keller (2007) and Cameron et al.(2005) show that technological transfers (including R\&D spillovers) take place through international trade. ${ }^{6}$ Keller (2002) also shows that international R\&D spillovers depends negatively on the distance between countries. ${ }^{7}$ Vandenbussche, Aghion and Meghir (2006) find that tertiary education has a higher growth-enhancing effect, at the aggregate level, the closer to the technology frontier a country is. While we find limited supporting evidence in favor of the trade channel of technological diffusion in our sample, we confirm the role of $\mathrm{R} \& \mathrm{D}$ and of human capital at the industry level.

The role of product market policies in speeding up the diffusion of productivity best practices across OECD countries has been emphasized by Scarpetta and Tressel (2002), Nicoletti and Scarpetta (2003), and Conway et al. (2006). ${ }^{8}$ However, Scarpetta and Tressel (2002) and Nicoletti and Scarpetta (2003) do not cover the late 1990s, which prevents analyzing the impact of reforms on the diffusion of ICT goods across OECD countries. Conway et al. (2006) focus on labor productivity, and do not explore the role of labor market institutions, human capital or R\&D in fostering technology adoption. They also do not analyze the process of ICT capital deepening at the industry level. Finally, the role of labor market regulations was emphasized by Scarpetta and Tressel (2002, 2004), and from a macroeconomic perspective by Gust and Marquez (2004) and Kent and Simon (2007). ${ }^{9}$

The paper is also related to the literature on the source of the productivity surge in the US in the second half of the 1990s (Jorgenson and Stiroh, 2000, Oliner and Sichel, 2000). Stiroh (2002) shows that the most ICT-intensive industries experienced significantly larger productivity gains than other industries. He also finds a strong link between ICT capital shares and the relative acceleration of labor productivity, e.g. the productivity surge occurred in industries that produce and use information technologies more intensively. ${ }^{10}$ Jorgenson, Ho

different types of capital and labor (see section III.D). However, problems remain with productivity data and national statistical agencies are in the process of gaining experience in the compilations of these data. This suggests that estimates may be subject to errors (see for instance Australian Bureau of Statistics, 2007).

${ }^{6}$ Coe and Helpman (1995) first emphasized the role of international trade in international R\&D transfers.

${ }^{7}$ Keller (2004) provides a survey of the micro and macro literature on R\&D spillovers.

${ }^{8}$ Griffith and Harrison (2006) showed that EU Single Market Programme reforms have increased competition, and subsequently raised innovation intensity and productivity growth for manufacturing sectors.

${ }^{9}$ Salgado (2002) also explores the impact of structural reforms (trade, product market and labor market) on aggregate productivity growth. He finds no significant effect in the short-run, and some significant positive effect of product market and trade reforms on productivity growth in the long-run.

${ }^{10}$ Stiroh (2006) finds that the second productivity surge in the U.S. (2000-04) is more broad-based, and that non-ICT industries also experienced productivity gains. 
and Stiroh (2005) find that, both at the industry and aggregate level, economic growth in the U.S. over 1977-2000 was explained by investments in information technology and higher education. Turning to international comparisons, Inklaar et al. (2005) performed growth accounting decompositions at the industry level and found that ICT capital deepening took place in service sectors both in the U.S. and in four European countries, but that the contribution to aggregate growth is lower in Europe. Moreover, these sectors did not experience a TFP acceleration in European countries. Inklaar et al. (2006) show that differences in productivity growth and levels are to a large extent driven by market services. They suggest that productivity growth in services industries in Canada and Australia may be related to a process of convergence (low initial levels of productivity). In this paper, we go one step further by exploring which factors could explain why the process of convergence accelerated in Australia precisely after 1990, and not before. More generally, we relate the diffusion of the "ICT revolution" across countries and within industries to existing policies in the labor and product markets, and to R\&D and human capital.

What are the channels through which less stringent product market policies may enhance productivity growth? ${ }^{11}$ Beyond the traditional textbook argument that competition brings about allocative efficiency, recent theories and evidence have emphasized the impact of competition on innovation in a dynamic Schumpeterian environment. In a Schumpeterian world, firms' ability to innovate, adopt new technologies and reorganize their production structure depends on competitive pressures reflected in the process of entry and exit. Acemoglu et al. (2006) argue that benefits from competition policies are larger in more advanced economies when innovation-based growth strategies become more important. Aghion et al. (2005) develop a model in which there is an inverted U-shape relationship between competition and innovation, and find support for the theory from UK firm level data. Aghion et al. (2006) find a positive impact of entry on productivity in more technologically advanced, less mature industries.

Our results on the labor market are consistent with a number of theories. For instance, Saint Paul (2002) shows that countries with a rigid labor market specialize in low risk "secondary innovations" which improve existing products, while countries with more flexible labor markets tend to produce new products. His theory implies that labor market rigidity is more likely to harm innovation and productivity in more high-skill, innovative industries. Similarly, Hopenhayn and Rogerson (1993) and Bertola (1994) show how productivity can be reduced as employment protection distorts employment away from an efficient allocation, thereby reducing capital accumulation and growth. ${ }^{12}$ All in all, existing theories suggest that labor market rigidities are more likely to have adverse effects on productivity in industries that depend more on innovation and the creation of new goods.

\footnotetext{
${ }^{11}$ See also Scarpetta and Tressel (2002) for a discussion.

12 There also exists a line of theoretical literature showing that employment protection may have positive effects on productivity by encouraging firm specific human capital accumulation through longer job tenure (see Saint Paul (1997)).
} 
The paper is organized as follows. Section II describes Australia's productivity performance and the reforms undertaken in the 1990s. Section III presents the empirical model and the data. Section IV discusses our empirical results. Section V concludes.

\section{PRODUCTIVITY PERFORMANCE AND REFORMS IN AUSTRALIA}

\section{A. Australian Productivity Performance since 1990: Key Facts}

Since the end of the 1991 recession, Australia has experienced a strong productivity performance. Aggregate labor productivity has increased by about 30 percent between 1990 and 2006, driven by strong productivity growth throughout most of the 1990s, but followed by a slow-down in recent years. This overall performance is similar to that of the United States over the same period and better than OECD average. ${ }^{13}$ Productivity gains were accompanied by strong gross fixed capital formation and increased labor participation so that, by 2007, the unemployment rate had fallen to a 32 years low. During this period, Australia has also strongly increased investments in Information and Communication Technologies (ICT).

Figure 1. Australia's Productivity Performance

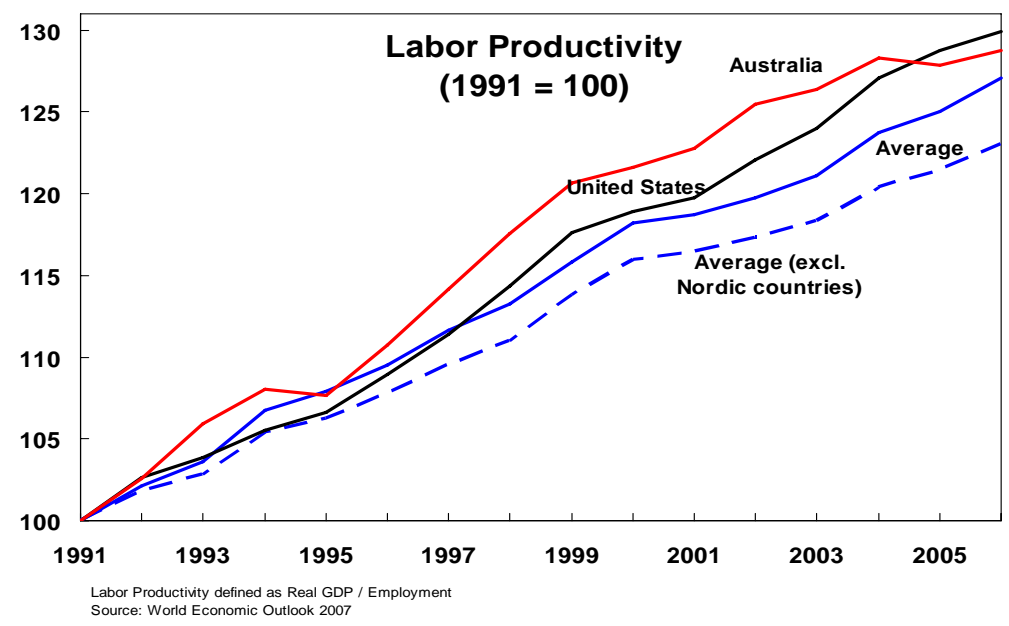

\footnotetext{
${ }^{13}$ The average in Figure 1 includes all of the 15 countries used in the regression analysis. Nordic countries (Denmark, Finland and Sweden) experienced the strongest productivity gains, followed by similar performances for the U.S., the U.K., and Australia.
} 


\section{Figure 2. Investments in Information and Communication Technologies}

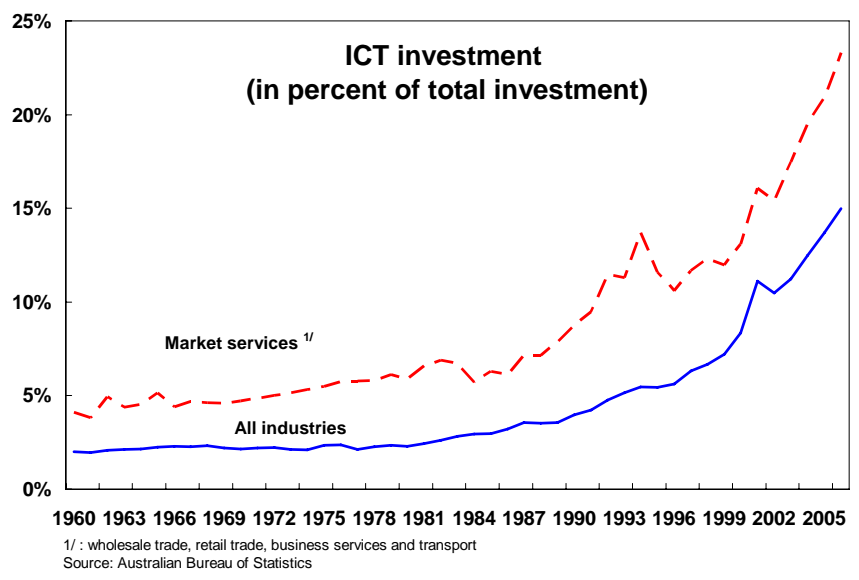

Labor productivity gains were unevenly distributed across sectors, and were mainly located in market services, including wholesale trade and retail trade, as well as in business services and transports in more recent years. ${ }^{14}$ Hence, from a supply-side point of view, market services have been the main drivers of real GDP growth over the past 16 years. Other sectors experienced mixed performance: manufacturing's contribution has been declining steadily, while agriculture and mining's output growth and productivity performance followed cyclical patterns with no clear trend.

Figure 3. Sectoral Contributions to Real GDP Growth

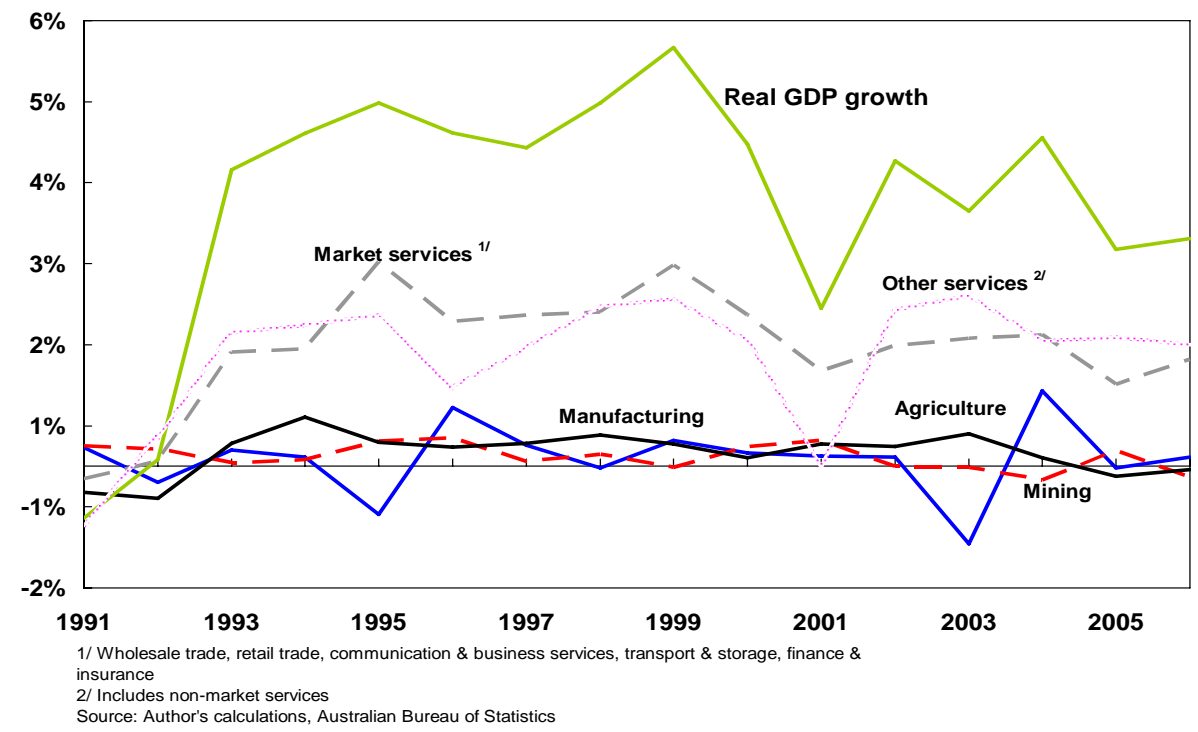

${ }^{14}$ Author's calculations. See also Inklaar et al. (2006) for growth accounting. 


\section{B. The Reform Process in Australia}

Since the late 1980s, Australia has undertaken broad and far reaching reforms in the areas of the product and labor markets which have enhanced the capacity of the economy to respond flexibly to shocks. Australia has also followed sound monetary and fiscal policies.

In the area of the labor market, there has been a long-term trend of industrial relations reforms. By the end of the 1980s, the costs associated with the centralized system of wage bargaining and setting, whereby wage increases were passed on across the board to all industries, had became apparent. Labour market reforms undertaken during the period of this analysis included the following steps. In 1991, under the Keating government, bargaining agreements on employment conditions were decentralized at the enterprise level so as to better align wages to productivity gains. The 1993 reforms expanded and accelerated the use of enterprise bargaining, while in 1996, the Coalition Government furthered the decentralization process by introducing the possibility of individual contracts through the Australian Workplace Agreements (the powers of the Australian Industrial Relations Commission were also reduced). These steps, together with other reforms and ongoing structural changes of industrialized economies around the world, contributed in the secular decline in the unionization rate. ${ }^{15}$ As a result of these consecutive reforms, Australia stands out among OECD countries as a country with a flexible labor market characterized by a low level of corporatism, a decentralized wage bargaining system, and a flexible employment protection legislation.

Figure 4. Employment Protection Legislations in OECD Countries

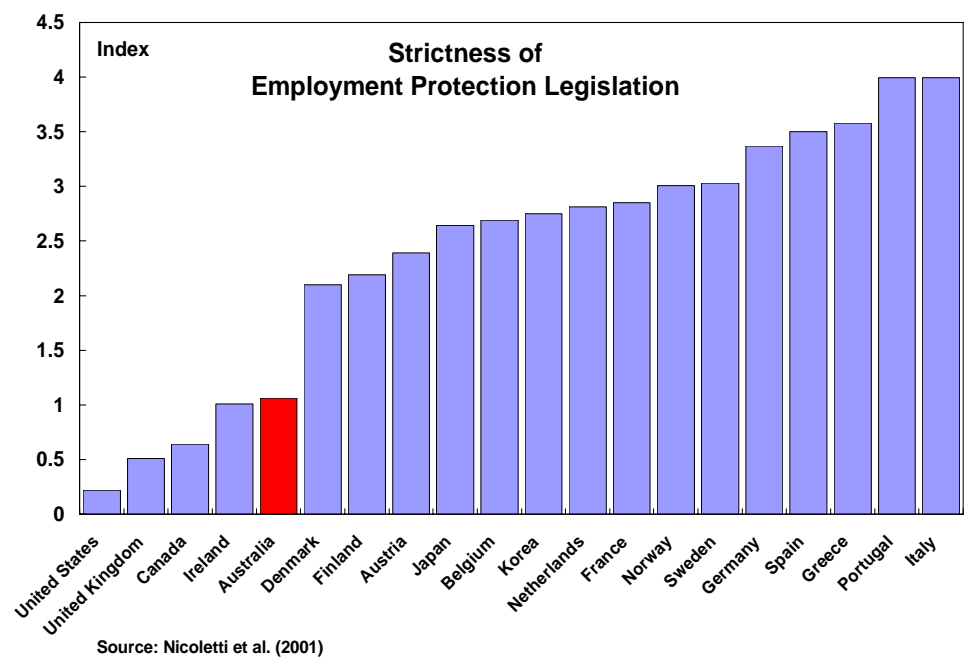

\footnotetext{
${ }^{15}$ While outside the period of this analysis, the 2006 "Workchoices" reforms aimed at further simplifying workplace agreement procedures by forming a single national industrial system, reducing the number of minimum employment conditions, and liberalizing unfair dismissal laws.
} 
Australia has also significantly deregulated its product markets since the end of the 1980s. ${ }^{16}$ Significant trade liberalization was initiated in the 1980s. Starting in 1988, phased reductions in tariffs were implemented across all industries, so that by the end of the 1990s virtually all tariffs have become negligible. Infrastructure reforms were also initiated in the late 1980s, covering deregulation and restructuring of air and coastal transport, and telecommunication. Public enterprises were also progressively commercialized, corporatized and privatized on a large scale. Between 1995 and 2000, the National Competition Policy (NCP) further reduced anti-competitive regulations, and reformed government businesses and the transport and utilities sectors. Going forward, the National Reform Agenda will continue (i) reducing anti-competitive barriers (energy, transport, infrastructure); (ii) simplifying regulations; and (iii) enhancing human capital.

\section{Figure 5. Product Market Reforms in Australia}

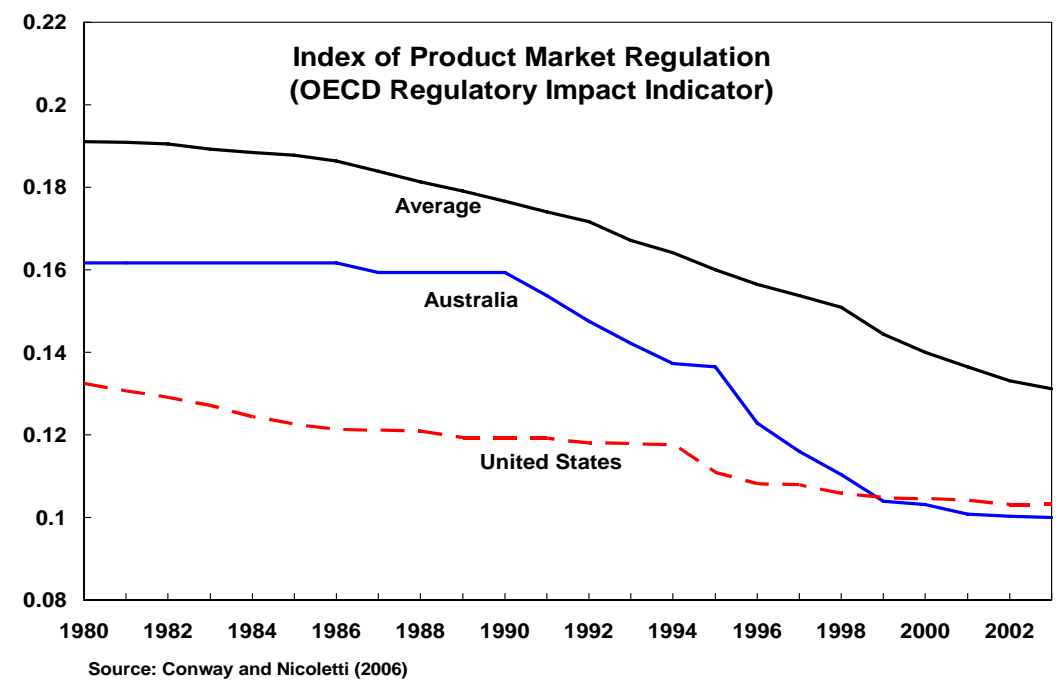

\section{EMPIRICAL MODEL AND DATA DESCRIPTION}

A close look at the data shows that productivity performance usually varies significantly across industries in the OECD. Moreover, reallocation of resources across industries has typically played a limited role in explaining cross-country differences in aggregate productivity growth in OECD countries. For these two reasons, we restrict our analysis to productivity performance at the industry level.

\section{A. Theory}

Consider a constant return to scale production function for industry $j$ in country $i$ :

\footnotetext{
${ }^{16}$ See Banks (2005) and Ziegelschmidt et al. (2005) for a more detailed description.
} 


$$
Y_{i j t}=A_{i j t} \cdot F_{i j}\left(K_{i j t}^{I C T}, K_{i j t}^{N I C T}, L_{i j t}\right)
$$

where $K^{I C T}$ is the stock of ICT capital services, $K^{\text {NICT }}$ the stock of other capital services, and $L$ a measure of the stock of labor services that accounts for the skill composition of labor (see the growth accounting methodology described below). The parameter $A$ is the Hicks neutral technology parameter (also called multifactor productivity or total factor productivity): it accounts for all technologies (defined loosely so as to also include organizational and managerial factors) that are not biased towards any factor of production. In this framework, innovations that are specific to one or another factor of production will be embodied in the definition of capital or labor inputs. For example, the direct effect of the ICT revolution appears as a change in the composition of capital services (from non-ICT to ICT capital services). Similarly, changes in human capital are embodied in the stock of labor services. Hence, any effects of ICT capital or human capital on MFP can be seen as an externality contributing to increasing returns at the industry level.

This production function assumes that, in each country, firms and industries can choose different combinations of factors of production. As in the standard neoclassical model, the Hicks-neutral world technology frontier in each industry $j$ is defined by:

$$
A_{\text {Fjt }}=\operatorname{Max}\left(A_{i j t}\right)
$$

In this world, Hicks-neutral technologies diffuse perfectly across countries if and only if, for each country $i$ : $A_{i j}=A_{F j}$. In addition, in the standard neoclassical model, the steady-state aggregate capital-labor ratio is a function of the Hicks-neutral technology parameter: $\frac{K_{i j}}{L_{i j}}=h\left(A_{i j}\right)$, where $K$ is a measure of the aggregate stock of capital services. ${ }^{17}$ Hence, in a steady-state, the ICT capital labor ratio will depend on the composition of capital between ICT and traditional capital goods (non-ICT) and the productivity parameter:

$$
\frac{K_{i j}^{I C T}}{L_{i j}}=\frac{K_{i j}^{I C T}}{K_{i j}} \cdot h\left(A_{i j}\right)
$$

\section{B. Empirical Specification}

We consider a linearized process of diffusion of Hicks-neutral multifactor productivity (MFP) across countries whereby, within each industry, the MFP level in country $i$ is influenced by technological transfers from the technology-frontier country. We assume that MFP for a given industry $j$ in country $i$ follows an auto-regressive distributed lag ADL $(1,1)$ process in which the level of MFP is co-integrated with the level of MFP of the technological frontier country $F .^{18}$ Note that, in this framework, the leader country $F$ is not necessarily the same across all industries, and can change over time within any industry $j$. Specifically, the dynamics of technology diffusion is modeled as:

\footnotetext{
${ }^{17}$ The relationship is log-linear for a Cobb-Douglas production function.

${ }^{18}$ Using industry data, a similar specification was used by Griffith et al. (2004), Scarpetta and Tressel (2002), Nicoletti and Scarpetta (2003), Cameron et al. (2005), and Conway et al. (2006). Vandenbussche et al. (2006), Kent and Simon (2007) and Gust and Marquez (2004) followed the same approach at the macroeconomic level.
} 


$$
\ln A_{i j t}=\beta_{1} \cdot \ln A_{i j t-1}+\beta_{2} \cdot \ln A_{F j t}+\beta_{3} \cdot \ln A_{F j t-1}+\lambda \cdot X_{i j t-1}+\varepsilon_{i j t}
$$

Assuming that, in each industry, MFP gaps are constant in the long run (a reasonable steadystate assumption that does not require convergence to the same level of technology across countries), the specification becomes:

$$
\Delta \ln A_{i j t}=\beta_{2} \Delta \ln A_{F j t}-\left(1-\beta_{1}\right) \ln \left(\frac{A_{i j t-1}}{A_{F j t-1}}\right)+\lambda \cdot X_{i j t-1}+\varepsilon_{i j t}
$$

The diffusion of ICT technologies across countries can be analyzed by looking at the dynamics of the ICT capital to labor ratio. In a similar fashion, the short-run dynamics of the ICT capital labor ratio is modeled as:

$$
\ln K L_{i j t}^{I C T}=\alpha_{1} \cdot \ln K L_{i j t-1}^{I C T}+\alpha_{2} \cdot \ln K L_{F j t}^{I C T}+\alpha_{3} \cdot \ln K L_{F j t-1}^{I C T}+\mu \cdot X_{i j t-1}+\gamma \ln \left(K^{I C T} / K\right)_{i j t-1}+\varepsilon_{i j t}^{\prime}
$$

Again, with constant ICT capital labor ratio gaps in the long run, the short-run dynamics becomes:

$$
\Delta \ln K L_{i j t}^{I C T}=\alpha_{2} \cdot \Delta \ln K L_{F j t-1}^{I C T}-\left(1-\alpha_{1}\right) \cdot \ln \left(\frac{K L_{i}^{I C T}}{K L_{F}^{I C T}}\right)_{j t-1}+\mu \cdot X_{i j t-1}+\gamma \cdot \ln \left(\frac{K^{I C T}}{K}\right)+\varepsilon_{i j t}^{\prime}
$$

We include a full set of countries fixed effects to control for unobserved country factors that could affect productivity; they also permit to control for possible systematic differences across countries in the measurement of variables of interest. Finally, we include a full set of industry-year fixed effects to control for general trends and co-movements of industry MFP across countries. ${ }^{19}$ The empirical analysis is performed at an annual frequency, rather than over longer periods. There are two reasons for this choice: (1) taking averages over several years may smooth out and therefore hide productivity accelerations, or decelerations, depending on which period of the cycle the average is performed; ${ }^{20}(2)$ the impact of reforms on productivity growth may materialize relatively quickly and fade out after several years, so averages may not pick up such dynamics very well.

\section{The Long-Run Impact of Covariates X on MFP and Capital-Labor Ratio Levels}

The long-run impact of a vector of covariates $X$ on the MFP gap across countries in any given industry $j$ can be derived from the previous specification. In the long run, any potential gaps in the levels of MFP will be constant, implying that MFP growth will be the same for all countries in each industry. The marginal impact of $\mathrm{X}$ on the steady-state MFP gap is then given by:

$$
\frac{\partial \ln \left(\frac{A_{i j}}{A_{F j}}\right)}{\partial X}=\frac{\lambda}{1-\beta_{1}}
$$

\footnotetext{
${ }^{19}$ Industry-year fixed effects also control for the MFP growth of the leader in each industry.

${ }^{20}$ Cycles are unlikely to be synchronized across countries and industries, so, in a cross-country setting it would be extremely difficult to compute several year averages all starting at the same stage of cycles in different countries and industries.
} 
Therefore the covariates X can be seen as affecting MFP growth in the short run, and affecting convergence of MFP levels across countries in the long run.

\section{Data Sources and Methodology}

The main source of information for European countries, the U.S. and Japan is the EU KLEMS database that provides growth accounts at a disaggregated sectoral level. ${ }^{21}$

As explained below, and in contrast to previous industry datasets, this dataset provides information on the composition of inputs that is comparable across countries. The EU KLEMS database is augmented with the Industry Growth Accounting (IGA) database for Australia and Canada, which is constructed following a similar methodology. ${ }^{22}$ We also used the OECD STAN dataset for additional growth accounting information, the OECD ANBERD 2 \& 3 datasets for R\&D, and the OECD bilateral trade database. Countries included are Australia, Austria, Belgium, Canada, Denmark, Finland, France, Germany, Italy, Japan, Netherlands, Spain, Sweden, the U.K., and the U.S. The sectoral decomposition retained for the analysis is given in Table 1 . Sectors related to the public sector were dropped from the analysis. ${ }^{23}$ When sectoral aggregations varied across dataset, standard growth accounting methods were used to obtain comparable levels of aggregations for each variable used in the analysis. The index of employment protection legislation is from Nicoletti et al. (2001) and the index of product market regulations is from Conway et al.(2006b).

Table 1. Sectoral Decomposition

Industry List (Market Econom y)

\begin{tabular}{|c|c|c|c|}
\hline & ISIC Rev. 3 Code & Industry Name & ICT Classification \\
\hline & $01-05$ & Agriculture, forestry and fishing & Non-IC T \\
\hline & $10-14$ & Mining and quarrying & Non-ICT \\
\hline & $15-16$ & Food products & Non-ICT \\
\hline & $17-19$ & Textile, clothing \& leather & Non-IC T \\
\hline & 20 & W ood products & Non-IC T \\
\hline & $21-22$ & Paper, printing \& publishing & IC T using \\
\hline & 23 & Petroleum and coal products & Non-IC T \\
\hline & 24 & Chemical products & Non-IC T \\
\hline & 25 & Rubber \& Plastics & Non-IC T \\
\hline & 26 & Non-metallic mineral products & Non-IC T \\
\hline & $27-28$ & Metal products & Non-IC T \\
\hline & 29 & M achinery and equipment, N.E.C. & IC T using \\
\hline & $30-33$ & Electrical and optical equipment & IC $T$ producing \\
\hline & $34-35$ & Transport equipment & Non-IC T \\
\hline & $36-37$ & Manufacturing N.E.C.; recycling & IC T using \\
\hline & $40-41$ & Electricity, gas and water supply & Non-ICT \\
\hline & 45 & Construction & Non-IC T \\
\hline & $50-52$ & Wholesale and retail trade; repairs & IC $T$ using \\
\hline & 55 & Hotels and restaurants & Non-IC T \\
\hline & $60-63$ & - Transport \& storage & Non-IC T \\
\hline 21 The datab & 64 & Post and telecommunications & IC $\mathrm{T}$ producing \\
\hline \multirow{2}{*}{ in Timmer $\epsilon$} & $65-67$ & Financial intermediation & IC T using \\
\hline & $71-74$ & Business services & IC $T$ using \\
\hline
\end{tabular}




\section{E. Growth Accounting}

The growth accounting methodology used in the database is described in Jorgenson et al. (2005). The stock of capital services is based on the aggregation of various real capital assets. For each real asset type $s$, the capital stock is constructed using the perpetual inventory method (industry subscript $j$ is omitted for simplicity):

$$
K_{S, t}=(1-\delta) \cdot K_{S, t-1}+I_{S, t}
$$

Growth in the aggregate capital stock is measured by the sum of capital service flows for each asset type weighted by the share of each component in the value of capital compensation averaged over two years $\left(v_{S, t}^{K}=\frac{1}{2} \cdot\left[v_{S, t}+v_{S, t-1}\right]\right):{ }^{24}$

$$
\Delta \ln K_{t}=\Sigma_{S}{ }_{S}^{-K} v_{S, t} \cdot \Delta \ln K_{S, t}
$$

In a competitive market, the rate of return on each capital good is equal to the rental price for each asset type s:

$$
r_{S, t}=\left(R_{t}+\delta_{S}-\dot{p}_{S, t}\right) \cdot p_{S, t}
$$

where the rental price of the asset is the sum of a nominal rate of return $R$, a depreciation rate $\delta_{S}$ specific to the asset $s$, minus the growth rate $\dot{p}_{S, t}$ of the asset price. Details on the construction of the rental prices can be found in Timmer et al. (2007b) for the EU KLEMS database and in Inklaar et al. (2005) for the GGDC Industry Growth Accounting Database.

Using this methodology, two series of capital stock are constructed: one for Information and Communication Technology capital goods ( $K^{I C T}$ ) and one for other types of capital goods ( $K^{\text {NICT }}$ ). ICT capital goods include computing equipment, communication equipment and softwares. ${ }^{25}$

In each industry $j$, under the assumption of a competitive factor market that equalizes the price of each factor of production to its marginal product, full input utilization and constant returns to scale, the log change in value added $V A_{j}$ can be decomposed as the sum of log changes in the two types of capital, labor and Hicks neutral multi-factor productivity A, which is therefore derived as a residual:

$$
\Delta \ln V A_{j}=\bar{v}^{L} \Delta \ln L_{j}+\bar{v}^{-I C T} \Delta \ln K_{j}{ }^{I C T}+\bar{v}^{-N I C T} \Delta \ln K_{j}{ }^{N I C T}+\Delta \ln A_{j}
$$

As for the capital stock, labor input is also measured as labor services (number of hours worked) aggregated over different types of labor, including different skill levels (industry subscript $j$ omitted for simplicity): ${ }^{26}$

\footnotetext{
${ }^{24}$ This methodology allows to account for the fact that some assets are more productive than others.

${ }^{25}$ For non-ICT capital goods, the IGA database includes transport equipment, non-ICT machinery and equipment and non-residential structures. The EU KLEMS database includes a broader set of capital goods.

${ }^{26}$ See Timmer et al. (2007) for a description of the labor service variable in the EU KLEMS database. For Australia, labor service including the distinction between skilled and unskilled labor inputs are from Scarpetta and Tressel (2002).
} 


$$
\Delta \ln L=\sum_{k}^{-L} v_{k}^{L} \Delta \ln L_{k}
$$

where $\bar{v}_{k}^{L}$ is the 2 year average share of labor type $k$ in total labor compensation.

For all aggregation purposes, we follow the "aggregation over industries" method first developed by Jorgenson, Gollop and Fraumeni (1987) and described in Jorgenson et al. (2005). This methodology allows to perform a growth accounting decomposition at the industry level while avoiding the assumption of perfect mobility of inputs across industries. For instance, aggregate real aggregate value added is defined as a Tornqvist index over industry value-added:

$$
\Delta \ln V A=\sum_{j} \bar{w}_{j} \Delta \ln V A_{j}
$$

where $\bar{w}_{j}$ is the two period average share of the nominal value-added of industry $\mathrm{j}$ in total nominal value added.

By identification, one can derive aggregate growth in capital services and labor services as:

$$
\begin{aligned}
& \left(\begin{array}{l}
\Delta \ln K^{N I C T}=\sum_{j}\left(\frac{\bar{v}_{j}^{N I C T} \bar{w}_{j}}{-{ }^{N I C T}}\right) \cdot \Delta \ln K_{j}^{N I C T} \\
\Delta \ln K^{I C T}=\sum_{j}\left(\frac{-v_{j}^{I C T} \bar{w}_{j}}{-I C T}\right) \cdot \Delta \ln K_{j}^{I C T} \\
\Delta \ln L=\sum_{j} \frac{\bar{v}_{j}^{L} \bar{w}_{j}}{\bar{v}^{L}} \cdot \Delta \ln L_{j}
\end{array}\right. \\
& \text { Where: } \bar{v}^{\text {NICT }}=\sum_{j} \bar{w}_{j}-\bar{v}_{j}^{N I C T}, \bar{v}^{I C T}=\sum_{j} \bar{w}_{j} \bar{v}_{j} \text { and } \bar{v}^{L}=\sum_{j} \bar{w}_{j} \bar{v}_{j}^{L} .
\end{aligned}
$$

Aggregation of other variables are done by using the value-added shares of each industry $\bar{w}_{j}$ as weights.

\section{F. Level Accounting}

In each industry, an index of MFP is defined by comparing each country to a hypothetical "average” country for each year: ${ }^{27}$

$$
\log \hat{A}_{i j t}=\log \left(\frac{V A_{i j t}}{\overline{V A}_{j t}}\right)-\hat{v}^{L} \log \left(\frac{L_{i j t}}{\bar{L}_{j t}}\right)-\hat{v}^{I C T} \log \left(\frac{K_{i j t}^{I C T}}{\bar{K}_{j t}^{I C T}}\right)-\hat{v}^{N I C T} \log \left(\frac{K_{i j t}^{N I C T}}{\bar{K}_{j t}^{N I C T}}\right)
$$

where an upper bar stands for an average across countries of value added, labor and capital stocks. The factor shares $\hat{v}^{L}, \hat{v}^{I C T}$ and $\hat{v}^{\text {NICT }}$ are simple arithmetic averages of the factor

\footnotetext{
${ }^{27}$ See Scarpetta and Tressel (2002) and Inklaar et al. (2006) for a more detailed description. The method was originally proposed by Caves, Christensen and Diewert (1982) and is the level accounting analogy to the Tornqvist level approach used in the industry growth accounting decomposition.
} 
shares in the country considered and factor share of the "average" country. The factor shares of the "average" country are geometric averages over all countries' factor shares.

Next, the (log) level of MFP relative to the leading country is defined as the log difference between the index of MFP of a given country and the index of MFP of the country with the highest index in a particular industry and year:

$$
\log \left(\frac{\hat{A}_{i j t}}{\hat{A}_{F j t}}\right) \text { where } \log \left(\hat{A}_{F j t}\right)=\operatorname{Max}_{i}\left\{\log \hat{A}_{i j t}\right\} \text {. }
$$

\section{G. Exchange Rates for International Comparisons}

To be comparable across countries, all variables used in the growth accounting must be expressed in a common currency. Until recently only GDP PPP exchange rates were available. The problem is that, in presence of systematic differences in price evolutions across industries, the use of GDP PPPs is likely to result in systematic biases when comparing productivities across countries (see for instance Sorensen, 2001). Such systematic differences in price evolutions across industries are very likely to be significant, as illustrated for example by the drastic price reductions of ICT goods over the past 15 years relative to the price of other goods. In this study, we use the gross output PPPs constructed by Timmer et al. (2007c) ${ }^{28}$ They find considerable variations of output prices across countries within industries, suggesting that PPP does not hold within industries. Moreover, prices relative to the US price level also vary importantly across industries within countries, suggesting that industry level price adjustments are important. For instance, in Australia, food products' relative price is 1 (e.g. relative to the US price level), but it is 1.70 for Radio, Television and Communication Equipment, 1.53 for Textiles but only 0.85 for Coke and Pretroleum Products. $^{29}$

\section{EMPIRICAL ANALYSIS}

\section{A. A First Look at the Data}

Table 2 presents descriptive statistics of the key variables. Over the period studied (1980-2003), industry labor productivity grew at 2.8 percent on average in our sample. Growth of multi-factor productivity reached 1.3 percent on average, and the distance to the MFP leader was 39 percent on average. ${ }^{30}$ Australian industries experienced somewhat higher labor productivity and MFP growth, and were farther away from the MFP leader on average,

\footnotetext{
${ }^{28}$ The data are publicly available at http://www.euklems.net/

${ }^{29}$ See Timmer et al.(2007c), Table 5.

${ }^{30}$ Distance to the frontier is computed as $1-\frac{\hat{A}_{i j t}}{\hat{A}_{F j t}}$. Other studies have found distances to the frontier at the industry level varying from 20 percent to 50 percent.
} 
but not significantly so (distance to the MFP leader was 43 percent on average).

Accumulation of ICT capital services was faster than that of more traditional capital goods: the ICT capital to labor ratio grew at 13.9 percent on average, while the non ICT capital to labor ratio grew at only 2.6 percent. Australia stands out as having experienced much faster accumulation of ICT capital than other countries in the sample, but not for other types of capital.

Table 3 shows that labor productivity growth is strongly correlated with MFP growth, suggesting that differences of labor productivity across industries and countries are mainly explained by differences in the efficiency of the use of factors, rather than by differences in capital-labor ratios across industries and countries. Hence, to explain differences in labor productivity, it is key to understand what determines the efficiency of the use of factors across industries and countries.

Table 4 shows MFP leaders in selected industries. Australia has consistently ranked well in mining and in transport and storages. The U.S. has been the leader in manufacturing industries taken as whole among OECD countries. Within manufacturing, Finland and the U.S. have been the two leaders in the production of ICT goods in recent years. Continental European countries have been the MFP leaders in services industries (such as wholesale and retail trade, business services). ${ }^{31}$ Relative MFP levels also change significantly over time, as illustrated by Australia's experience between 1980 and 2003 (Figure 6). The Figure also shows that the evolution of MFP levels over time has a strong industry-specific component. These patterns are generally consistent with industry labor productivity levels presented in Dolman et al. (2007), and suggest that industry-level studies are important to understand the evolution of countries' productivity levels.

Turning to policy variables, there are substantial variations in labor and product market regulations across OECD countries. The index of the strictness of employment protection legislation (EPL), which includes both regular and temporary contracts, is from Nicoletti et al. (2001)..$^{32}$ As shown on Figure 4, Anglo-Saxon economies (the U.S., the U.K, Canada, Australia and Ireland) have very flexible labor markets as measured by EPL, compared with other OECD countries. At the other extreme, Southern European countries (Spain, Portugal, Italy, Greece), as well as Germany have strict employment legislation. We consider the EPL index as a broad indicator of flexibility of the labor market.

Over the past decades, OECD countries have also deregulated their product markets significantly, as shown on Chart 5 (see Nicoletti et al. (2001), and Conway et al. 2005). ${ }^{33}$ By

\footnotetext{
${ }^{31}$ Leaders based on labor productivity are available upon request.

${ }^{32}$ Regulations for regular contracts include (i) procedural inconveniences faced by employers when dismissing a worker, (ii) advance notice of dismissal and severance payments, and (iii) standards and penalties for unfair dismissals. Regulations for temporary contracts include (i) the objective reasons for which they can be offered; (ii) the maximum number of successive renewals; and (iii) the maximum cumulated duration of the contract.

${ }^{33}$ See Conway and Nicoletti (2006) for description on the construction of the industry-specific product market regulatory impact variable.
} 
the end of the period, Australia has deregulated its product market significantly more than other OECD countries, reaching a level of product market regulation slightly below the U.S. level. The industry specific time-varying indicator of product market regulations is from Conway and Nicoletti (2006b), and measures the extent of anti-competitive product market regulations in non-manufacturing sectors as well as their 'knock-on' effects on manufacturing sectors. ${ }^{34}$

\section{B. Regression Results}

Basic convergence regressions for MFP growth and the ICT capital-labor ratio are reported in Table 5. The top panel presents the results for MFP growth. Based on the estimates shown in Column (1) of panel A, simple calculations imply that, for a typical industry with a 40 percent gap to the leader in that industry, the diffusion of technology across OECD countries implies an MFP growth of 0.21 percentage points annually on average. ${ }^{35}$ Given the actual annual MFP growth observed in the sample (1.3 percent), this implies that diffusion of technologies on average explains only about 15 percent of observed MFP growth. Columns (1) and (2) of Panel A also show that convergence of MFP levels has significantly slowed down over the past ten years. ${ }^{36}$

Interestingly, when allowing for a convergence factor specific to Australia, the average effect drops in size and significance, while the Australian effect is strongly significant (columns (3) and (4)). This suggests that Australia is one of the countries where convergence of MFP levels has played a significant role, and that, on average, convergence has not taken place in other OECD countries. Based on the estimated coefficients of column (3), and the average gap to the industry leader in Australia, simple back-of-the-envelope calculations imply that convergence led to an annual MFP growth of about 0.4 percent in Australia. Moreover, column (4) suggests that this faster convergence of MFP in Australia took place mainly after 1990. Finally, in columns (5) and (6) we show that the ICT revolution does not seem to have led to significantly different convergence experiences between ICT using, ICT producing and other industries on average (columns (5) and (6)). Finally, we also find that, in Australia, MFP in ICT using sectors has grown 0.1 percentage points faster than Australia's own average (based on the estimated coefficient of the Australia dummy in column (3)).

\footnotetext{
${ }^{34}$ Non-manufacturing sectors include electricity, gas and water supply, air and road transport, road freight, post and telecommunications (covered over 1975-2003), and retail distribution and professional business services for 1996-98 and 2003. The index is based on several sub-indices covering barriers to entry, public ownership, market structure, vertical integration and price controls. It also indirectly measure the indirect impact of these regulations for manufacturing sectors.

${ }^{35}$ This is computed as follows: $-0.0095 * \log (0.6)$.

${ }^{36}$ Conway et al. (2006) find a similar result when looking at convergence of labor productivity across OECD countries.
} 
Panel B of Table 5 explores convergence in the use of ICT inputs by looking at the convergence of ICT capital - labor ratios. Again, Australia appears as an outlier, and, as implied by the coefficient on the Australia dummy in column (3), has experienced an ICT capital deepening 3.5 percentage points above the sample average of 13.9 percent, an estimate consistent with the summary statistics discussed earlier. As with MFP, Australia's convergence of its ICT capital-labor ratio seems to explain most of the average convergence effect (columns (3) and (4) ).

Table 6 explores the role of product market regulations (PMR) in explaining differences in the convergence of MFP best practices at the industry level across OECD countries. The average effect of PMR is not robustly significant, when entered either as a linear effect or a non-linear effect that depends on the gap to the MFP leader. However, we find a robustly significant positive effect of product market deregulation in ICT using industries, but no effect in other industries. These effects are robust when controlling for potential externalities (or increasing returns to scale) caused by human capital or ICT capital. ${ }^{37}$ Interestingly, we also find a very significant and positive effect of human capital on MFP growth (but only for the period 1990-2003), even though our measure of MFP has already netted out the composition effects of labor input. This result is consistent with recent studies emphasizing the role of human capital in speeding convergence at the aggregate level (see Vandenbussche et al., 2006).

In Table 7, we explore the impact of labor market flexibility on MFP growth. Column (1) shows a strongly negative correlation between the index of EPL and industry level MFP growth across countries. In column (2) we split industries according to the share of high skill workers in total hours worked in each country. Industries that are above the country median are labeled "high skill industries", and those below "low-skill industries". We show that the negative association between MFP growth and the EPL index is strongly significant in highskill industries, but not in low skill industries. This result is robust to the inclusion of country fixed effects, and remains significant after controlling for the share of high skill workers in labor compensation and the share of ICT capital in total capital compensation. Hence, labor market flexibility seems particularly important for MFP growth in industries that are more intensive in human capital.

Table 8 shows that both labor market flexibility for high skill industries and product market deregulation for ICT using industries have contributed in boosting MFP growth in OECD countries. Moreover, increased flexibility of the labor market and product market reforms seem to explain the "Australian effect" identified in Table 5 (see column (7)). We continue to find that a higher share of skill workers in labor compensation remains significantly associated with faster MFP growth after $1990 .^{38}$ However, we do not find any clear signs of externalities caused by ICT capital within industries on average.

\footnotetext{
${ }^{37}$ Conway et al. (2006) obtain a similar result for labor productivity.

${ }^{38}$ The effect of human capital is insignificant when country fixed effects are omitted. This might reflect problems of comparability of measures of human capital levels across countries. However, deviation from country and industry means are likely to be better measured. The fact that we find a strong effect within
} 
Finally, Table 9 shows that countries with more flexible labor markets seem to have experienced a faster ICT capital deepening than other countries. This result is not driven by different compositions of the stock of capital (we control for the previous year's share of ICT capital in total capital) or by a lower initial stock of ICT capital (we control for the initial ICT capital-labor ratio). Results on the role of product market regulations are more ambiguous: the effects of PMR become insignificant when the degree of labor market flexibility is accounted for, or when industry-year fixed effects are included, suggesting that any negative association between the PMR index and MFP growth reflected industries' specificities.

\section{Robustness Tests}

A number of robustness tests are reported in Appendix Tables 1-3. First, we show that we obtain very similar results when looking at the effects of labor market flexibility and product market regulations on labor productivity growth instead of MFP growth (Appendix 1). Next, we show that the main results are not driven by any specific country in the sample. In Appendix 2, we report the coefficient and t-statistics for the variable of interest when countries are dropped one-by-one, for the regression with the highest and lowest p-value respectively. This confirms that our results are not driven by any outlier country in the sample. Finally, we report regressions using 3 year averages instead of regressions at an annual frequency. Using 3 year average may help smooth out noise in the data, but may also reduce the precision of estimated effects, for the reasons discussed in section III.

\section{Do Reforms Explain Australia's Productivity Performance?}

Table 10 explores whether product and labor market reforms can explain Australia's long period of high productivity growth. It uses estimates of various regressions to compare actual and predicted MFP performances. In Panel A, we ask whether product market reforms undertaken since the early 1990s can explain the order of magnitude of average productivity growth acceleration in ICT using industries after 1991 relative to the 1980s. MFP growth reached 1.2 percent on average each year between 1991 and 2003, compared with 0.4 percent between 1980 and 1990. In ICT-using industries, the PMR index went down from 0.22 to 0.18 in Australia between the early 1990s and 2003. Given an average gap to the leader of about 40 percent, we can estimate the MFP growth acceleration caused by PMR reforms using regression estimates: we obtain a predicted acceleration of MFP growth of 0.1 percent on average each year (using the change in end of period PMR indices to estimate the MFP acceleration). Moreover, given that the gap to the leader had somewhat widened during the 1980s from 42 percent to 47 percent, the catch-up effect also implies an acceleration of MFP growth of 0.07 percent. Overall, this implies that less than 20 percent of Australia's productivity acceleration is explained by product market reforms and convergence, so product market deregulations alone cannot explain Australia’s productivity acceleration.

countries after 1990, however, is strongly suggestive of human capital externalities at the industry level, within countries. 
The impact of product market reforms was not negligible, but other factors must have also contributed to the productivity performance. ${ }^{39}$

In contrast, the effect of labor market flexibility as implied by our regression results seems to be of the order of magnitude of observed MFP growth differentials across countries, and therefore may be a better candidate in explaining MFP catch-up within industries in OECD countries in general, as well as Australia's specific experience in the 1990s after the labor market was deregulated. Panel B tests whether differences of EPL across countries are good predictors of differences in MFP growth over the period 1990-2003. For this exercise we compare the countries with the most flexible labor markets with the countries with the least flexible labor markets. We find that EPL explains MFP growth differentials quite well: the four countries with the most flexible labor markets in 2001 (the US, the UK, Australia and Canada) experienced an MFP growth of 1.13 percent in high skill industries during that period. The countries with the less flexible labor markets (Germany, Spain and Italy) experienced an annual MFP growth of 0.68 percent in high skill industries. From the estimated cofficient on the EPL variable, our regression results imply that differences in EPL across the two groups predict an MFP growth differential of 0.58 percentage points for the countries with flexible labor markets relative to the countries with inflexible labor markets. Hence, the MFP growth differential observed between the two groups of countries $(0.44$ percent) is of the order of magnitude of the differential predicted by the regression results (0.58 percent).

\section{E. Other Determinants of MFP Convergence: The Role of Human Capital and R\&D}

Table 11 shows that our key results on labor market flexibility and product market deregulation remain significant when controlling for various other variables, including R\&D intensity, and trade related variables. We also uncover a strong and significant association between R\&D intensity and MFP growth, as in other studies (see in particular Griffith et al. (2004)). Specifically, we find a strong indirect benefit of R\&D, but no direct significant association between R\&D intensity and MFP growth after controlling for the indirect effect. ${ }^{40}$ The indirect effect of $R \& D$ is proxied by an interaction term between $R \& D$ intensity and the relative level of MFP. This indirect effect of R\&D suggests that domestic R\&D may enhance technological transfer, by increasing domestic absorptive capacity, thus allowing countries to import and adapt to foreign innovations faster.

The size of the effect of R\&D intensity on MFP growth may be biased because of endogeneity, and therefore should be interpreted cautiously. R\&D intensity, which measures an outcome, could reflect an industry's expected future productivity performance: industries may do more R\&D when they expect to be able to innovate more easily. Moreover, R\&D spendings may only reflect a country's industry structure, and the overall business

\footnotetext{
${ }^{39}$ The magnitudes of the effects obtained in our regressions are consistent with those found in earlier studies (see Scarpetta and Tressel ,2002, Nicoletti and Scarpetta, 2003, and Conway et al., 2006).

${ }^{40}$ Previous studies (Griffith et al, 2004, Cameron et al., 2005) had found a direct positive effect of R\&D on MFP growth. See also Cardarelli (2001b).
} 
environment, as shown in Davis and Tunny (2005). ${ }^{41}$ However, controlling for industryspecific co-movements should partially, but not entirely address such concerns, by netting out any industry specific patterns. A simple, albeit rough way to evaluate the importance of endogeneity concerns is to see how the size and significance of the R\&D intensity variable change when it is lagged by more than one year. We find that the direct effect of $R \& D$ intensity becomes insignificant when it is lagged 3 years or more. ${ }^{42}$ There are two possible, non-mutually exclusive explanations for this result: (a) the initial effect was driven by endogeneity, (b) the actual direct effect of $R \& D$ on productivity materializes during the first two years. In contrast, we find that the indirect effect of R\&D via the adoption of foreign technologies remain strongly significant even after 5 years, suggesting that the indirect effect may be less likely to be driven by endogeneity. ${ }^{43}$ The estimates of Table 11 suggest that, if Australian firms increased their R\&D intensity from 1.8 percent to the sample average of 3.6 percent, MFP growth would increase by 0.04 percent annually. ${ }^{44}$

We also show in Table 11 that the effect of human capital becomes strongly significant when controlling for the effects of $\mathrm{R} \& \mathrm{D}$, giving support to the argument that human capital may create externalities even at the industry level, and may have indirect effects on labor productivity, in addition to direct effects on labor productivity caused by input composition effects. The effects are economically significant: an increase in the share of high-skill workers in total labor compensation by one standard deviation (13 percent) would lead to an acceleration of industry MFP growth of 0.5 percent annually. Dolman et al. (2007) and Davis and Rahman (2006) show that Australia has narrowed the gap in educational attainment in recent years as younger cohorts of workers are more educated that older cohorts.

Finally, we also control for trade related factors, but none are significantly and robustly correlated with MFP growth. We control for the export orientation of each sector, as measured by the share of exports in industry value-added. We also control for technological diffusion through trade measured by the import weighted R\&D intensity of U.S. industries. Indeed, a number of papers (including Coe and Helpman (1995) and Acharya and Keller (2007)) have found a strong and significant effect of technology diffusion through trade. ${ }^{45}$ However we do not find any significant positive effects of trade induced technological diffusion in our sample of countries.

\footnotetext{
${ }^{41}$ They also find a weak correlation between R\&D and more direct measures of innovation, suggesting that lower levels of R\&D do not necessarily imply that a country is less innovative. See Productivity Commission (2007) for a thorough analysis of Australia’s public support of science and innovation.

42 These results are not reported and are available upon request.

43 These results are not reported and are available upon request.

${ }^{44}$ An increase of R\&D intensity by one standard deviation to 8.9 percent would increase MFP growth by about 0.1 percent annually.

${ }^{45}$ Keller (2002) shows that geography and distance to innovators affect international technological diffusion. See Keller (2004) for a survey.
} 


\section{CONCLUSION}

This paper has looked at Australia's past productivity performance in the broader context of technology diffusion across OECD countries. In many respects, Australia has been an outlier since the early 1990s: Australia has enjoyed a long economic expansion and experienced strong productivity gains; Australia has also undertaken many reforms, in particular in the labor and product market areas. We show that these reforms, when taken together, may largely explain the productivity performance of the Australian economy.

More broadly, we find that, among OECD countries, reforms of the product market significantly affect MFP growth in industries that use ICT intensively. Moreover, labor market flexibility seems to have a strong and positive impact on MFP in sectors that are more intensive in human capital, and tends to foster the accumulation of ICT capital. Finally, we confirm the importance of R\&D for the speed of technological diffusion, and find evidence of human capital externalities at the industry level. However, this does not necessarily imply that more R\&D—one input of innovation among many others-would always result in higher productivity. 


\section{REFERENCES}

Acemoglu, D., Aghion, P., and Zilibotti, F., 2006, “Distance to Frontier, Selection and Economic Growth,” Journal of the European Economic Association, Vol. 4, No. 1 pp. 37-74.

Acharya, R., and W. Keller, 2007, “Technology Transfer Through Imports,” CEPR Discussion Paper No. 6296.

Aghion, P., Bloom, N., Griffith, R., Blundell, R., and Howitt, P., 2005, “Competition and Innovation: An Inverted U Relationship,” Quarterly Journal of Economics, Vol. 120 No. 2, pp. 701-28.

— — Blundell, R., Griffith, R., Howitt, P., and S. Prantl, 2006, “The Effects of Entry on Incumbent Innovation and Productivity,” (unpublished; Cambridge, Massachusetts: Harvard University).

Australian Bureau of Statistics, 2007, "Experimental Estimates of Industry Multifactor Productivity,” Information Paper (5260.0.55.001).

Banks, G., 2005, “Structural Reform Australian-Style: Lessons for Others?” Presentation to the IMF, World Bank and OECD, May 2005, Productivity Commission, Canberra.

Bertola, G., 1994, “Flexibility, Investment and Growth,” Journal of Monetary Economics, Vol. 34, No. 2, pp. 215-38.

Cameron, G., Proudman J., S. Redding, 2005, “Technological Convergence, R\&D, Trade and Productivity Growth,” European Economic Review, Vol. 49, pp. 775-807.

Caves, D., Christensen, L., and E. Diewert, 1982, "Multilateral Comparisons of Output, Input, and Productivity Using Superlative Index Numbers,” Economic Journal, Vol. 92.

Coe, D., and E. Helpman, 1995, “International R\&D Spillovers,” European Economic Review, Vol. 39, pp. 859-87.

Conway, P., de Rosa, D., Nicoletti, G., and F. Steiner, 2006a, "Regulation, Competition and Productivity Convergence,” OECD Economics Department Working Papers No. 509 (Paris: OECD Publishing).

Conway, P., and G. Nicoletti, 2006b, "Product Market Regulation in the Non-Manufacturing Sectors of OECD Countries: Measurements and Highlights,” OECD Economics Department Working Papers No. 530 (Paris: OECD Publishing).

Conway, P., Janod, V., and G. Nicoletti, 2005, "Product Market Regulation in OECD Countries: 1998 to 2003” OECD Economics Departments Working Papers No.419 (Paris: OECD Publishing). 
Davis, G., and J. Rahman, 2006, "Perspectives on Australia’s Productivity Prospects,” Australian Treasury Working Paper 2006-04 (Canberra: Australia).

Davis, G., and G. Tunny, 2005, "International Comparisons of Research and Development,” Economic Roundup, Spring, Australian Treasury (Canberra: Australia).

Dolman, B., Parham, D., and S. Zheng, 2007, “Can Australia Match U.S. Productivity Performance?” Productivity Commission Staff Working Paper (Canberra: Australia).

Griffith, R., Redding, S., and J. Van Reenen, 2004, "Mapping the Two Faces of R\&D: Productivity Growth in a Panel of OECD Industries”, Review of Economics and Statistics, Vol. 86, No. 4, pp. 883-95 (first version 2000).

Griffith, R., and R. Harrison, 2006, "Product Market Reform and Innovation in the EU,” CEPR Discussion Paper No. 5849.

Gust, C., and J. Marquez, 2004, "International Comparisons of Productivity Growth: The Role of Information Technology and Regulatory Practises,” Labour Economics, Vol. 11 No. 1, pp.33-58.

Hopenhayn, H., and R. Rogerson, 1993, “Job Turnover and Policy Evaluation: A General Equilibrium Analysis,” Journal of Political Economy, Vol. 101, No. 5, pp. 915-38.

Inklaar, R., O'Mahony, M., and M. P. Timmer, 2005, “ICT and Europe's Productivity Performance; Industry-Level Growth Account Comparisons with the United States," Review of Income and Wealth, Vol. 51, No. 4, pp. 505-36.

— Productivity in Services and Goods Production,” GGDC Research Memorandum, GD-89.

Cardarelli, R., 2001a, “Is Australia a “New Economy?” Selected Issues Paper (Washington: International Monetary Fund).

— 2001b, “Technology Transfer and R\&D: A Cross-Country Regression,” Selected Issues Paper (Washington: International Monetary Fund).

Jorgenson, D., Ho, M., and K. Stiroh, 2005, "Growth of U.S. Industries and Investments in Information Technology and Higher Education,” in Measuring Capital in the New Economy, ed. by Carol Corrado, John Haltiwanger and Daniel Sichel (Chicago: University of Chicago Press).

Jorgenson, D., and K. Stiroh, 2000, "Raising the Speed Limit: U.S. Economic Growth in the Information Age,” Brookings Papers on Economic Activity: 1, pp. 125-211, Brookings Institution. 
Keller, W., 2004, “International Technology Diffusion,” Journal of Economic Literature, Vol. XLII, 752-82.

_ 2002, “Geographic Localization and International Technology Diffusion,” American Economic Review, Vol. 92, pp. 120-42.

Kent, C., and J. Simon, 2007, "Productivity Growth: The Effect of Market Regulations,” Reserve Bank of Australia, RDP 2007-04 (Sydney: Australia).

Nicoletti, G., and S. Scarpetta, 2003, "Regulation, Productivity and Growth,” Economic Policy, April, pp. 9-72.

Nicoletti, G., Bassanini, A., Ernst, E., Jean, S., Santiago, P., and P. Swaim, 2001, "Product and Labor Markets Interactions in OECD Countries," OECD Economics Department Working Paper No. 312 (Paris: OECD Publishing).

OECD, 2003, ICT \& Economic Growth: Evidence from OECD Countries, Industries and Firms (Paris: OECD Publishing).

Oliner, S., and D. Sichel, 2000, "The Resurgence of Growth in the Late 1990s: Is Information Technology the Story?” Journal of Economic Perspectives, Vol. 14, No.4, pp. 3-22.

Parham, D., Roberts, P., and Sun, H., 2001, Information Technology and Australia's Productivity Surge, Productivity Commission Staff Research Paper, AusInfo, (Canberra: Australia).

Productivity Commission, 2004, "ICT Use and Productivity: A Synthesis from Studies of Australian Firms,” Commission Research Paper (Canberra: Australia).

_ 2007, “Public Support for Science and Innovation,”Productivity Commission Research Report” (Canberra: Australia).

Salgado, R., 2002, "Impact of Structural Reforms on Productivity Growth in Industrial Countries,” IMF Working Paper 02/10 (Washington: International Monetary Fund).

Saint Paul, G., 1997, Dual Labor Markets - A Macroeconomic Perspective (Cambridge, Massachusetts: MIT Press).

Saint Paul, G., 2002, "Employment Protection, International Specialization, and Innovation,” European Economic Review, Vol. 46, pp. 375-95.

Stiroh, Kevin, 2002, "Information Technology and the U.S. Productivity Revival: What Do the Industry Data Say?” American Economic Review. 
— , 2004, "Reassessing the Impact of IT in the Production Function: A Meta-Analysis and Sensitivity Tests,” Federal Reserve Bank of New York.

— 2006, "The Industry Origins of the Second Surge of U.S. Productivity Growth," (unpublished; New York: Federal Reserve Bank of New York).

Scarpetta, S., and T. Tressel, 2002, "Productivity and Convergence in a Panel of OECD Industries: Do Regulations and Institutions Matter?” OECD Economics Department Working Paper No. 342 (Paris: OECD Publishing).

— , 2004, "Boosting Productivity via Innovation and Adoption of New Technologies: Any Role for Labor Market Institutions?” World Bank Policy Research Paper 3273 (Washington: World Bank).

Sorensen, A., 2001, "Comparing Apples and Oranges: Productivity Convergence and Measurement Across Industries and Countries: Comment," American Economic Review, Vol. 91, No. 4, pp.1160-67.

Timmer, M., Ypma, G. and B. van Ark, 2007c, "PPPs for Industry Output: A New Dataset for International Comparisons,” Groningen Growth and Development Centre, Research Memorandum GD-82 (Holland: University of Groningen).

Timmer, M.P., O’Mahony, M., and B. van Ark, 2007, The EU KLEMS Growth and Productivity Accounts: An Overview (unpublished; Holland: University of Groningen).

Timmer, M., van Moergastel T., and E. Stuivenwold, 2007b, EU KLEMS Growth and Productivity Accounts, Version 1.0, Part I Methodology (unpublished; Holland: University of Groningen).

Ziegelschmidt, H., Koutsogeorgopoulou, V., Bojornerud, S., and M. Wise, 2005, "Product Market Competition and Economic Performance in Australia," OECD Economics Department Working Papers No. 451 (Paris: OECD Publishing). 
Table 2. Summary Statistics (1980-2003) ${ }^{1 /}$

\begin{tabular}{|c|c|c|c|}
\hline Variable & Obs & Mean & Std. Dev. \\
\hline MFP growth & 4481 & $1.3 \%$ & $3.8 \%$ \\
\hline MFP growth -Australia & 325 & $1.5 \%$ & $3.8 \%$ \\
\hline MFP growth - United States & 383 & $1.1 \%$ & $3.9 \%$ \\
\hline Distance to MFP frontier & 4481 & $39.3 \%$ & $19.0 \%$ \\
\hline Distance to frontier - Australia & 325 & $43.4 \%$ & $17.8 \%$ \\
\hline Distance to frontier - United States & 383 & $36.7 \%$ & $17.9 \%$ \\
\hline Labor productivity growth & 4481 & $2.8 \%$ & $4.0 \%$ \\
\hline Labor productivity growth - Australia & 325 & $3.1 \%$ & $4.5 \%$ \\
\hline Labor productivity growth - United States & 383 & $2.8 \%$ & $4.0 \%$ \\
\hline ICT capital deepening & 4481 & $13.9 \%$ & $7.5 \%$ \\
\hline ICT capital deepening - Australia & 325 & $17.7 \%$ & $6.4 \%$ \\
\hline ICT capital deepening - United States & 383 & $15.7 \%$ & $6.5 \%$ \\
\hline Non-ICT capital deepening & 4481 & $2.6 \%$ & $3.1 \%$ \\
\hline Non-ICT capital deepening - Australia & 325 & $2.4 \%$ & $3.6 \%$ \\
\hline Non-ICT capital deepening - United States & 383 & $2.2 \%$ & $2.9 \%$ \\
\hline R\&D intensity & 2944 & $3.6 \%$ & $8.2 \%$ \\
\hline R\&D intensity - Australia & 236 & $1.8 \%$ & $2.6 \%$ \\
\hline R\&D intensity - United States & 254 & $3.8 \%$ & $6.0 \%$ \\
\hline $\begin{array}{l}\text { High skill labor compensation (in percent of } \\
\text { total labor compensation) }\end{array}$ & 3912 & $15.9 \%$ & $13.5 \%$ \\
\hline $\begin{array}{l}\text { Hours worked by high skill workers (in } \\
\text { percent of total hours worked) }\end{array}$ & 3920 & $10.9 \%$ & $11.1 \%$ \\
\hline $\begin{array}{l}\text { Annual percent change in share of hours } \\
\text { worked by high skill workers }\end{array}$ & 3895 & $4.4 \%$ & $8.7 \%$ \\
\hline $\begin{array}{l}\text { ICT capital compensation (in percent of total } \\
\text { compensation) }\end{array}$ & 4481 & $12.6 \%$ & $12.6 \%$ \\
\hline Employment protection legislation index & 4481 & 2.24 & 1.18 \\
\hline Product market regulation (PMR) & 4214 & 0.22 & 0.18 \\
\hline Annual percent change in PMR & 4214 & $-1.7 \%$ & $3.2 \%$ \\
\hline ICT using industries & 4481 & $29.4 \%$ & \\
\hline ICT producing industries & 4481 & $8.7 \%$ & \\
\hline Other industries & 4481 & $62.0 \%$ & \\
\hline
\end{tabular}

${ }^{1 /}$ Summary statistics are computed on the sample of regression (1) Table 5 
Table 3. Correlations

\begin{tabular}{|c|c|c|c|c|c|c|c|c|c|}
\hline & MFP growth & $\begin{array}{l}\text { ICT capital } \\
\text { deepening }\end{array}$ & $\begin{array}{c}\text { Non-ICT capital } \\
\text { deepening }\end{array}$ & $\begin{array}{l}\text { productivity } \\
\text { growth }\end{array}$ & $\begin{array}{l}\text { Growth in share } \\
\text { of hours by high } \\
\text { skill workers }\end{array}$ & $\begin{array}{l}\text { share of high skill } \\
\text { workers in total } \\
\text { labor comp. }\end{array}$ & $\begin{array}{l}\text { share of ICT } \\
\text { capital in total } \\
\text { capital comp. }\end{array}$ & $\begin{array}{l}\text { Product } \\
\text { Market } \\
\text { Regulation }\end{array}$ & $\begin{array}{l}\text { Employment } \\
\text { Protection } \\
\text { Legislation }\end{array}$ \\
\hline MFP growth & 1 & & & & & & & & \\
\hline ICT capital deepening & $\begin{array}{r}0.0018 \\
0.86\end{array}$ & 1 & & & & & & & \\
\hline Non-ICT capital deepening & $\begin{array}{r}-0.0008 \\
0.94\end{array}$ & $\begin{array}{r}0.2836 \\
0.00\end{array}$ & 1 & & & & & & \\
\hline Labor productivity growth & $\begin{array}{r}0.9021 \\
0.00\end{array}$ & $\begin{array}{r}0.1034 \\
0.00\end{array}$ & $\begin{array}{r}0.1898 \\
0.00\end{array}$ & 1 & & & & & \\
\hline $\begin{array}{l}\text { Growth in share of hours by } \\
\text { high skill workers }\end{array}$ & $\begin{array}{r}-0.0255 \\
0.01\end{array}$ & $\begin{array}{r}0.04 \\
0.00\end{array}$ & $\begin{array}{r}0.0187 \\
0.09\end{array}$ & $\begin{array}{r}0.004 \\
0.66\end{array}$ & 1 & & & & \\
\hline $\begin{array}{l}\text { share of high skill workers } \\
\text { in total labor comp. }\end{array}$ & $\begin{array}{r}-0.0243 \\
0.01\end{array}$ & $\begin{array}{r}-0.0389 \\
0.00\end{array}$ & $\begin{array}{r}-0.0626 \\
0.00\end{array}$ & $\begin{array}{r}-0.0037 \\
0.68\end{array}$ & $\begin{array}{r}-0.1234 \\
0.00\end{array}$ & 1 & & & \\
\hline $\begin{array}{l}\text { share of ICT capital in total } \\
\text { capital comp. }\end{array}$ & $\begin{array}{r}-0.0454 \\
0.00\end{array}$ & $\begin{array}{r}-0.0754 \\
0.00\end{array}$ & $\begin{array}{r}0.0102 \\
0.32\end{array}$ & $\begin{array}{r}-0.0355 \\
0.00\end{array}$ & $\begin{array}{r}0.0021 \\
0.82\end{array}$ & $\begin{array}{r}0.2064 \\
0.00\end{array}$ & 1 & & \\
\hline Product Market Regulation & $\begin{array}{r}-0.0113 \\
0.31\end{array}$ & $\begin{array}{r}-0.0491 \\
0.00\end{array}$ & $\begin{array}{r}-0.0087 \\
0.46\end{array}$ & $\begin{array}{r}0 \\
1.00\end{array}$ & $\begin{array}{r}0.0315 \\
0.01\end{array}$ & $\begin{array}{r}-0.0942 \\
0.00\end{array}$ & $\begin{array}{r}0.231 \\
0.00\end{array}$ & 1 & \\
\hline $\begin{array}{l}\text { Employment Protection } \\
\text { Legislation }\end{array}$ & $\begin{array}{r}-0.0116 \\
0.22\end{array}$ & $\begin{array}{r}-0.2044 \\
0.00\end{array}$ & $\begin{array}{r}0.1024 \\
0.00\end{array}$ & $\begin{array}{r}-0.0263 \\
0.00\end{array}$ & $\begin{array}{r}0.0018 \\
0.86\end{array}$ & $\begin{array}{r}-0.3187 \\
0.00\end{array}$ & $\begin{array}{r}-0.0154 \\
0.10\end{array}$ & $\begin{array}{r}0.1477 \\
0.00\end{array}$ & , \\
\hline
\end{tabular}

Note: $p$-values are in italics 
Table 4. Multi-Factor Productivity Leaders

\begin{tabular}{|c|c|c|c|c|}
\hline \multicolumn{2}{|l|}{ Industry } & No. 1 & No.2 & No.3 \\
\hline \multirow[t]{2}{*}{ Agriculture } & 1990 & Netherlands & United States & Belgium \\
\hline & 2003 & Germany & Denmark & Belgium \\
\hline \multirow[t]{2}{*}{ Mining } & 1990 & Denmark & Belgium & Australia \\
\hline & 2003 & Denmark & United Kingdom & Australia \\
\hline \multirow[t]{2}{*}{ Total Manufacturing } & 1990 & United States & Belgium & Germany \\
\hline & 2003 & United States & Sweden & Finland \\
\hline \multirow[t]{2}{*}{ Electrical and Optical Equipment } & 1990 & Netherlands & Austria & Spain \\
\hline & 2003 & Finland & United States & France \\
\hline \multirow[t]{2}{*}{ Wholesale, retail trade } & 1990 & France & Netherlands & Germany \\
\hline & 2003 & France & Netherlands & Finland \\
\hline \multirow[t]{2}{*}{ Transport \& storage } & 1990 & Netherlands & Australia & United States \\
\hline & 2003 & Netherlands & United States & Australia \\
\hline \multirow[t]{2}{*}{ Business Services } & 1990 & Belgium & Netherlands & Denmark \\
\hline & 2003 & Belgium & Netherlands & Sweden \\
\hline
\end{tabular}


Figure 6. Australian Industries MFP levels (relative to U.S.)
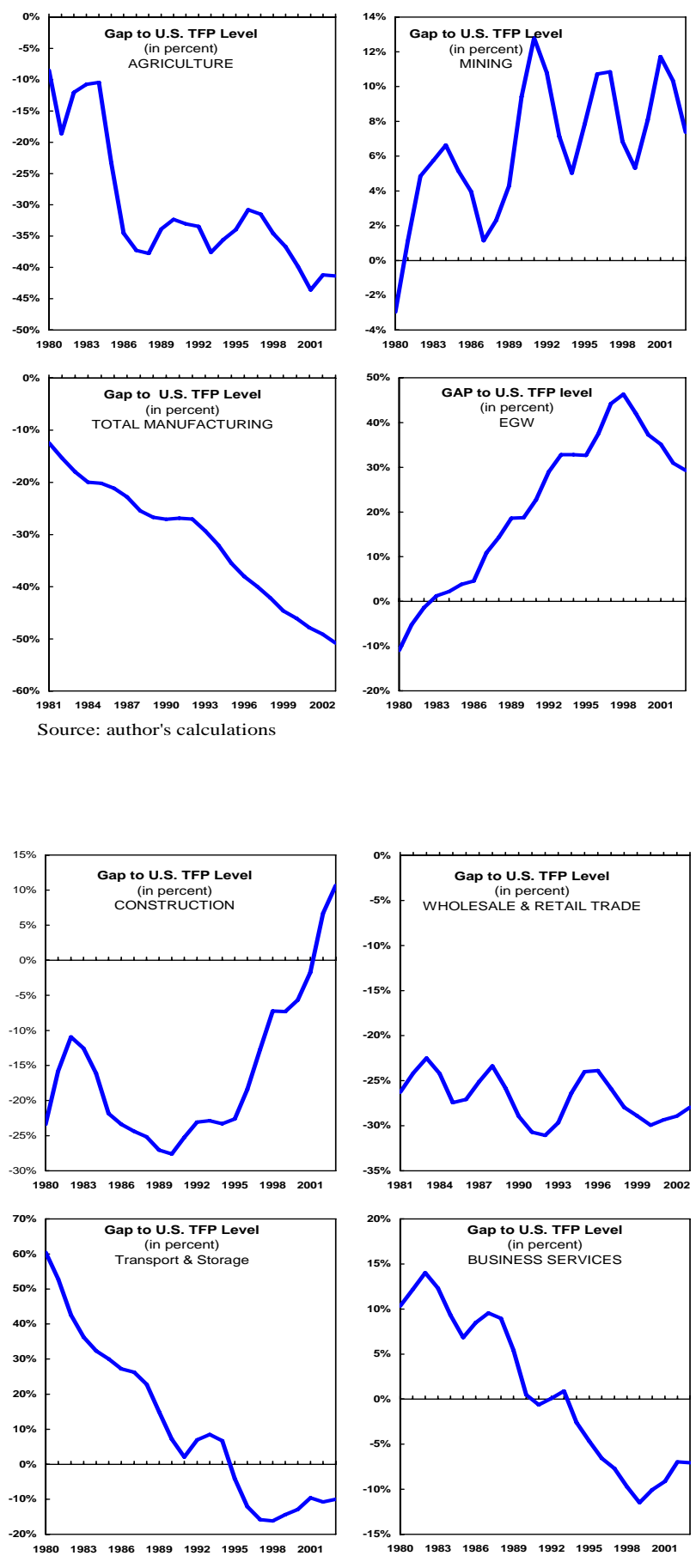

Source: author's calculations 


\title{
Table 5. Convergence of Australian Industries' Technology Level in a Panel of OECD Countries
}

\author{
Panel A. Multi-Factor Productivity
}

Dependent variable: annual MFP growth

\begin{tabular}{|c|c|c|c|c|c|c|}
\hline & (1) & $\begin{array}{c}(2) \\
1980-1995\end{array}$ & (3) & $\begin{array}{c}(4) \\
1980-1990\end{array}$ & (5) & (6) \\
\hline TFP level, relative to leader (t-1) & $\begin{array}{c}-0.0095 \\
{[3.11]^{* * *}}\end{array}$ & $\begin{array}{c}-0.02 \\
{[5.74]^{* * *}}\end{array}$ & $\begin{array}{c}0.00003 \\
{[0.02]}\end{array}$ & $\begin{array}{c}-0.01 \\
{[2.82]^{* * *}}\end{array}$ & & \\
\hline $\begin{array}{l}\text { TFP level, relative to leader (t-1) } \\
\text { (ICT using industries) }\end{array}$ & & & & & $\begin{array}{c}-0.008 \\
{[2.30]^{* *}}\end{array}$ & $\begin{array}{c}-0.008 \\
{[2.38]^{* *}}\end{array}$ \\
\hline $\begin{array}{l}\text { TFP level, relative to leader (t-1) } \\
\text { (ICT producers) }\end{array}$ & & & & & $\begin{array}{c}-0.013 \\
{[2.28]^{* *}}\end{array}$ & $\begin{array}{c}-0.013 \\
{[2.18]^{* *}}\end{array}$ \\
\hline $\begin{array}{l}\text { TFP level, relative to leader (t-1) } \\
\text { (Non High Tech industries) }\end{array}$ & & & & & $\begin{array}{c}-0.010 \\
{[3.08]^{* * *}}\end{array}$ & $\begin{array}{c}-0.009 \\
{[2.92]^{* * *}}\end{array}$ \\
\hline $\begin{array}{l}\text { TFP level, relative to leader (t-1) } \\
\text { Australia specific (interaction with dummy variable) } \\
\text { Australia (relative to average) } \\
\text { (dummy variable for Australia) }\end{array}$ & & & $\begin{array}{c}-0.019 \\
{[2.06]^{* *}} \\
0.011 \\
{[2.35]^{* *}}\end{array}$ & $\begin{array}{l}-0.017 \\
{[1.53]} \\
0.009 \\
{[1.25]}\end{array}$ & & \\
\hline ICT using in Australia & & & & & & $\begin{array}{r}0.01 \\
{[2.64]^{* * *}}\end{array}$ \\
\hline Observations & 4481 & 2758 & 4472 & 1626 & 4481 & 4481 \\
\hline R-squared $^{1 /}$ & 0.02 & 0.02 & 0.001 & 0.01 & 0.02 & 0.02 \\
\hline Country fixed effects & YES & YES & NO & NO & YES & YES \\
\hline
\end{tabular}

Robust t statistics in brackets, observations are clustered by country-year.

* significant at $10 \%$; ** significant at $5 \%$; *** significant at $1 \%$

$\mathrm{F}$ test of equality of convergence parameters for ICT using, ICT producing and Non-ICT sectors (Regression 5): $\mathrm{p}$ value $=0.53$

1/ R-squared exclude industry-year fixed effects

Note: TFP levels relative to leader are expressed in Logs. Regressions are on the full sample (1980-2003), unless indicated 


\section{Table 5. continued}

\section{Panel B. ICT capital deepening}

Dependent variable: annual growth in ICT capital labor ratio

\begin{tabular}{|c|c|c|c|c|c|c|}
\hline & (1) & $(2)$ & (3) & $\begin{array}{c}(4) \\
1980-1990\end{array}$ & (5) & (6) \\
\hline ICT capital-labor ratio, relative to leader (t-1) & $\begin{array}{c}-0.006 \\
{[4.27]^{* * *}}\end{array}$ & $\begin{array}{c}-0.003 \\
{[2.15]^{* *}}\end{array}$ & $\begin{array}{l}0.003 \\
{[1.66]}\end{array}$ & $\begin{array}{l}0.002 \\
{[0.57]}\end{array}$ & $\begin{array}{c}-0.003 \\
{[2.20]^{* *}}\end{array}$ & \\
\hline $\begin{array}{l}\text { ICT capital-labor ratio, relative to leader (t-1) } \\
\text { Australia specific }\end{array}$ & & & $\begin{array}{c}-0.016 \\
{[-4.21]^{* * *}}\end{array}$ & $\begin{array}{c}-0.016 \\
{[-3.12]^{* * *}}\end{array}$ & & \\
\hline $\begin{array}{l}\text { ICT capital-labor ratio, relative to leader (t-1) } \\
\text { (Non-ICT industries) }\end{array}$ & & & & & & $\begin{array}{l}-0.002 \\
{[-1.49]}\end{array}$ \\
\hline $\begin{array}{l}\text { ICT capital-labor ratio, relative to leader (t-1) } \\
\text { (ICT using industries) }\end{array}$ & & & & & & $\begin{array}{c}-0.004 \\
{[-2.07]^{* *}}\end{array}$ \\
\hline $\begin{array}{l}\text { ICT capital-labor ratio, relative to leader (t-1) } \\
\text { (ICT producing industries) }\end{array}$ & & & & & & $\begin{array}{c}-0.008 \\
{[-2.04]^{* *}}\end{array}$ \\
\hline Share of ICT capital in total capital (t-1) & $\begin{array}{l}-0.002 \\
{[0.92]}\end{array}$ & & & & & \\
\hline Share of ICT capital in total capital (t-2) & & $\begin{array}{c}-0.007 \\
{[3.56]^{* * *}}\end{array}$ & $\begin{array}{c}0.006 \\
{[2.83]^{* * *}}\end{array}$ & $\begin{array}{c}-0.008 \\
{[-2.34]^{* * *}}\end{array}$ & & $\begin{array}{c}-0.006 \\
{[-3.47]^{* * *}}\end{array}$ \\
\hline $\begin{array}{l}\text { Share of ICT capital in total capital (t-2) } \\
\text { (Non-ICT industries) }\end{array}$ & & & & & $\begin{array}{l}-0.004 \\
{[1.96]^{*}}\end{array}$ & \\
\hline $\begin{array}{l}\text { Share of ICT capital in total capital (t-2) } \\
\text { (ICT using industries) }\end{array}$ & & & & & $\begin{array}{c}-0.01 \\
{[3.30]^{* * *}}\end{array}$ & \\
\hline $\begin{array}{l}\text { Share of ICT capital in total capital (t-2) } \\
\text { (ICT producing industries) }\end{array}$ & & & & & $\begin{array}{c}-0.02 \\
{[5.72]^{* * *}}\end{array}$ & \\
\hline $\begin{array}{l}\text { Australia relative to average } \\
\text { (dummy variable for Australia) }\end{array}$ & & & $\begin{array}{c}0.035 \\
{[3.61]^{* * *}}\end{array}$ & $\begin{array}{l}0.020 \\
{[1.23]}\end{array}$ & & \\
\hline Observations & 4518 & 4378 & 4378 & 1760 & 4378 & 4378 \\
\hline R-squared ${ }^{1 /}$ & 0.27 & 0.27 & 0.03 & 0.03 & 0.27 & 0.27 \\
\hline Country fixed effects & YES & YES & NO & NO & YES & YES \\
\hline Industry-time fixed effects & YES & YES & YES & YES & YES & YES \\
\hline
\end{tabular}

Robust t statistics in brackets, observations are clustered by country-year.

* significant at $10 \%$; ** significant at $5 \%$; *** significant at $1 \%$

F test of equality of convergence parameters for ICT using, ICT producing and Non-ICT sectors: $p$ value $=0.0001$ (Reg. 5), p value $=0.3522$ (Reg. 6)

1/ R-squared exclude industry-year fixed effects

Note: TFP levels relative to leader are expressed in Logs. Regressions are on the full sample (1980-2003), unless indicated 


\section{Table 6. Impact of Product Market Regulations on MFP Growth}

Dependent variable: annual MFP growth

\begin{tabular}{|c|c|c|c|c|c|c|c|c|}
\hline & (1) & (2) & $\begin{array}{c}(3) \\
1990-2003\end{array}$ & (4) & $\begin{array}{c}(5) \\
1990-2003\end{array}$ & (6) & (7) & $\begin{array}{c}(8) \\
1990-2003\end{array}$ \\
\hline TFP level, relative to leader (t-1) & $\begin{array}{c}-0.010 \\
{[3.25]^{* * * *}}\end{array}$ & $\begin{array}{c}-0.013 \\
{[-3.75]^{* * *}}\end{array}$ & $\begin{array}{l}-0.007 \\
{[-1.47]}\end{array}$ & $\begin{array}{c}-0.014 \\
{[-3.82]^{* * *}}\end{array}$ & $\begin{array}{c}-0.008 \\
{[-1.68]^{*}}\end{array}$ & $\begin{array}{c}-0.009 \\
{[2.76]^{* * *}}\end{array}$ & $\begin{array}{c}-0.011 \\
{[-3.17]^{* * *}}\end{array}$ & $\begin{array}{l}-0.005 \\
{[-1.08]}\end{array}$ \\
\hline $\begin{array}{l}\text { TFP level, relative to leader (t-1) } \\
\text { Interacted with PMR }\end{array}$ & $\begin{array}{c}0.008 \\
{[1.81]^{*}}\end{array}$ & $\begin{array}{c}0.010 \\
{[1.91]^{*}}\end{array}$ & $\begin{array}{l}0.010 \\
{[1.41]}\end{array}$ & & & & & \\
\hline $\begin{array}{l}\text { TFPlevel, relative to leader (t-1) } \\
\text { Interacted with PMR in ICT using industries }\end{array}$ & & & & $\begin{array}{c}0.018 \\
{[3.04]^{* * * *}}\end{array}$ & $\begin{array}{c}0.021 \\
{[279]^{* * *}}\end{array}$ & & & \\
\hline $\begin{array}{l}\text { TFP level, relative to leader (t-1) } \\
\text { Interacted with PMR in ICT producing industries }\end{array}$ & & & & $\begin{array}{r}\mathbf{0 . 0 0 6} \\
{[0.65]}\end{array}$ & $\begin{array}{r}\mathbf{0 . 0 1 5} \\
{[0.73]}\end{array}$ & & & \\
\hline $\begin{array}{l}\text { TFP level, relative to leader (t-1) } \\
\text { Interacted with PMR in other industries }\end{array}$ & & & & $\begin{array}{r}\mathbf{0 . 0 0 5} \\
{[0.65]}\end{array}$ & $\begin{array}{r}\mathbf{0 . 0 0 4} \\
{[0.45]}\end{array}$ & & & \\
\hline Sectoral PMR(t-1) & $\begin{array}{l}\mathbf{0 . 0 0 8} \\
{[0.80]}\end{array}$ & $\begin{array}{l}-\mathbf{0 . 0 0 2} \\
{[-0.16]}\end{array}$ & $\begin{array}{r}-\mathbf{0 . 0 1 3} \\
{[-0.87]}\end{array}$ & $\begin{array}{r}\mathbf{0 . 0 0 3} \\
{[0.23]}\end{array}$ & $\begin{array}{r}-\mathbf{0 . 0 0 8} \\
{[-0.52]}\end{array}$ & & & \\
\hline High skill labor share (t-1) & & $\begin{array}{l}\mathbf{0 . 0 0 0 2} \\
{[1.43]}\end{array}$ & $\begin{array}{c}\mathbf{0 . 0 0 0 6} \\
{[2.86]^{* * *}}\end{array}$ & $\begin{array}{l}\mathbf{0 . 0 0 0 3} \\
{[1.52]}\end{array}$ & $\begin{array}{c}\mathbf{0 . 0 0 0 6} \\
{[2.96]^{* * *}}\end{array}$ & & $\begin{array}{l}0.0002 \\
{[1.09]}\end{array}$ & $\begin{array}{c}0.0006 \\
{[2.6]^{* * *}}\end{array}$ \\
\hline ICT capital share (t-1) & & & & $\begin{array}{c}0.0120 \\
{[1.85]^{*}}\end{array}$ & $\begin{array}{l}0.0153 \\
{[1.82]^{*}}\end{array}$ & & & \\
\hline $\begin{array}{l}\text { Sectoral PMR(t-1) } \\
\text { in ICT using }\end{array}$ & & & & & & $\begin{array}{c}-0.028 \\
{[2.21]^{* *}}\end{array}$ & $\begin{array}{c}-0.025 \\
{[-1.83]^{*}}\end{array}$ & $\begin{array}{c}-0.043 \\
{[-26]^{* * * *}}\end{array}$ \\
\hline $\begin{array}{l}\text { Sectoral PMR(t-1) } \\
\text { in ICT producing }\end{array}$ & & & & & & $\begin{array}{l}0.031 \\
{[1.08]}\end{array}$ & $\begin{array}{c}-0.068 \\
{[-1.87]^{*}}\end{array}$ & $\begin{array}{c}-0.0828416 \\
{[-1.59]}\end{array}$ \\
\hline $\begin{array}{l}\text { Sectoral PMR }(\mathrm{t}-1) \\
\text { in non-ICT }\end{array}$ & & & & & & $\begin{array}{l}0.016 \\
{[1.38]}\end{array}$ & $\begin{array}{l}0.020 \\
{[1.36]}\end{array}$ & $\begin{array}{c}0.0136761 \\
{[0.72]}\end{array}$ \\
\hline $\begin{array}{l}\text { Observations } \\
\text { R-squared }\end{array}$ & $\begin{array}{l}4214 \\
0.02\end{array}$ & $\begin{array}{l}3539 \\
0.03\end{array}$ & $\begin{array}{c}2235 \\
0.0349\end{array}$ & $\begin{array}{c}3539 \\
0.0255\end{array}$ & $\begin{array}{c}2235 \\
0.0377\end{array}$ & $\begin{array}{l}4214 \\
0.02\end{array}$ & $\begin{array}{l}3539 \\
0.026\end{array}$ & $\begin{array}{l}2235 \\
0.037\end{array}$ \\
\hline $\begin{array}{l}\text { Country fixed effects } \\
\text { Industry-time fixed effects }\end{array}$ & $\begin{array}{l}\text { YES } \\
\text { YES }\end{array}$ & $\begin{array}{l}\text { YES } \\
\text { YES }\end{array}$ & $\begin{array}{l}\text { YES } \\
\text { YES }\end{array}$ & $\begin{array}{l}\text { YES } \\
\text { YES }\end{array}$ & $\begin{array}{l}\text { YES } \\
\text { YES }\end{array}$ & $\begin{array}{l}\text { YES } \\
\text { YES }\end{array}$ & $\begin{array}{l}\text { YES } \\
\text { YES }\end{array}$ & $\begin{array}{l}\text { YES } \\
\text { YES }\end{array}$ \\
\hline
\end{tabular}

Robust t statistics in brackets, observations are clustered by country-year.

* significant at $10 \%$ ** significant at $5 \%$ *** significant at $1 \%$

Note: TFP levels relative to leader are expressed in Logs. Regressions are on the full sample (1980-2003), unless indicated 


\section{Table 7. Impact of Labor Market Institutions on MFP Growth}

Dependent variable: annual MFP growth

(1)

(2)

(3)

(4)

(5)

(6)

1990-2003

\begin{tabular}{lcccccc}
\hline TFP level, relative to leader (t-1) & -0.0005 & -0.00067 & -0.01002 & -0.01092 & -0.01093 & -0.00251 \\
& -0.39 & {$[0.34]$} & {$[3.18]^{* * *}$} & {$[3.12]^{* * *}$} & {$[3.12]^{* * *}$} & {$[0.65]$} \\
EPL & -0.002 & & & & & \\
& {$[-2.02]^{* *}$} & & & & & \\
EPL & & $-\mathbf{0 . 0 0 2 3}$ & $-\mathbf{0 . 0 0 1 5}$ & $-\mathbf{0 . 0 0 1 5}$ & $\mathbf{- 0 . 0 0 1 5}$ & $\mathbf{- 0 . 0 0 1 9}$ \\
High Skill industries & & {$[2.36]^{* *}$} & {$[3.04]^{* * *}$} & {$[3.15]^{* * *}$} & {$[3.16]^{* * *}$} & {$[3.68]^{* * *}$} \\
EPL & & -0.00095 & & & & \\
Low Skill industries & & {$[1.24]$} & & & & \\
High skill labor share (t-1) & & & & 0.00016 & 0.00015 & 0.00039 \\
& & & & {$[0.79]$} & {$[0.78]$} & {$[2.44]^{* *}$} \\
ICT capital share (t-1) & & & & & 0.00389 & 0.00454 \\
& & & & & {$[0.31]$} & {$[0.51]$} \\
\hline Observations & & & & & & \\
R-squared & 4481 & 4481 & 4481 & 3892 & 3892 & 2527 \\
Country fixed effects & 0.002 & 0.002 & 0.02 & 0.02 & 0.02 & 0.03 \\
Industry-time fixed effects & NO & NO & YES & YES & YES & YES \\
\hline
\end{tabular}

Robust t statistics in brackets, observations are clustered by country

* significant at $10 \%$; ** significant at $5 \%$; *** significant at $1 \%$

Note: TFP levels relative to leader are expressed in Logs. Regressions are on the full sample (1980-2003), unless indicated 


\section{Table 8. Disentangling the Effects of Product and Labor Market Institutions on MFP Growth}

Dependent variable: annual MFP growth

\begin{tabular}{|c|c|c|c|c|c|c|c|}
\hline & (1) & (2) & $\begin{array}{c}(3) \\
1990-2003\end{array}$ & (4) & (5) & $\begin{array}{c}(6) \\
1990-2003\end{array}$ & (7) \\
\hline TFP level, relative to leader (t-1) & $\begin{array}{c}-0.0029 \\
{[1.46]}\end{array}$ & $\begin{array}{c}-0.0030 \\
{[1.27]}\end{array}$ & $\begin{array}{c}-0.0002 \\
{[0.08]}\end{array}$ & $\begin{array}{c}-0.0112 \\
{[3.19]^{* * *}}\end{array}$ & $\begin{array}{c}-0.0115 \\
{[3.29]^{* * *}}\end{array}$ & $\begin{array}{c}-0.0037 \\
{[0.88]}\end{array}$ & $\begin{array}{l}-0.0023 \\
{[-0.98]}\end{array}$ \\
\hline $\begin{array}{l}\text { TFP level, relative to leader (t-1) } \\
\text { Interacted with PMR }\end{array}$ & $\begin{array}{c}0.010 \\
{[2.25]^{* *}}\end{array}$ & & & $\begin{array}{r}0.006 \\
{[1.31]}\end{array}$ & & & \\
\hline $\begin{array}{l}\text { TFP level, relative to leader (t-1) } \\
\text { Interacted with PMR in ICT using industries }\end{array}$ & & $\begin{array}{c}0.015 \\
{[2.45]^{* *}}\end{array}$ & $\begin{array}{c}0.016 \\
{[2.03]^{* *}}\end{array}$ & & $\begin{array}{c}0.016 \\
{[2.68]^{* * *}}\end{array}$ & $\begin{array}{c}0.016 \\
{[2.11]^{* *}}\end{array}$ & $\begin{array}{c}0.015 \\
{[2.47]^{* *}}\end{array}$ \\
\hline $\begin{array}{l}\text { TFP level, relative to leader (t-1) } \\
\text { Interacted with PMR in ICT producing industries }\end{array}$ & & $\begin{array}{l}-0.004 \\
{[0.36]}\end{array}$ & $\begin{array}{c}0.011 \\
{[0.57]}\end{array}$ & & $\begin{array}{l}-0.007 \\
{[0.73]}\end{array}$ & $\begin{array}{l}0.002 \\
{[0.12]}\end{array}$ & $\begin{array}{l}-0.005 \\
{[-0.47]}\end{array}$ \\
\hline $\begin{array}{l}\text { TFP level, relative to leader (t-1) } \\
\text { Interacted with PMR in other industries }\end{array}$ & & $\begin{array}{c}0.011 \\
{[1.74]^{*}}\end{array}$ & $\begin{array}{c}0.007 \\
{[0.91]}\end{array}$ & & $\begin{array}{c}0.004 \\
{[0.52]}\end{array}$ & $\begin{array}{l}0.003 \\
{[0.38]}\end{array}$ & $\begin{array}{l}0.009 \\
{[1.46]}\end{array}$ \\
\hline $\begin{array}{l}\text { TFP level, relative to leader (t-1) } \\
\text { Australia specific }\end{array}$ & & & & & & & $\begin{array}{l}-0.028 \\
{[-1.52]}\end{array}$ \\
\hline Australia relative to average & & & & & & & $\begin{array}{l}0.007 \\
{[0.7]}\end{array}$ \\
\hline EPL & $\begin{array}{l}-0.001 \\
{[1.37]}\end{array}$ & $\begin{array}{l}-0.001 \\
{[1.36]}\end{array}$ & $\begin{array}{l}-0.001 \\
{[0.71]}\end{array}$ & & & & \\
\hline $\begin{array}{l}\text { EPL } \\
\text { High skill industries }\end{array}$ & & & & $\begin{array}{c}-0.002 \\
{[3.70]^{* * *}}\end{array}$ & $\begin{array}{c}-0.002 \\
{[3.85]^{* * *}}\end{array}$ & $\begin{array}{c}-0.002 \\
{[4.04]^{* * *}}\end{array}$ & $\begin{array}{c}-0.002 \\
{[-3.48]^{* * *}}\end{array}$ \\
\hline High skill share (t-1) & $\begin{array}{c}0.00003 \\
{[0.25]}\end{array}$ & $\begin{array}{c}0.00003 \\
{[0.28]}\end{array}$ & $\begin{array}{c}0.00007 \\
{[0.57]}\end{array}$ & $\begin{array}{c}0.00016 \\
{[1.17]}\end{array}$ & $\begin{array}{c}0.00019 \\
{[1.37]}\end{array}$ & $\begin{array}{c}0.00045 \\
{[2.75]^{* * *}}\end{array}$ & $\begin{array}{c}0.000054 \\
{[0.56]}\end{array}$ \\
\hline ICT share $(\mathrm{t}-1)$ & $\begin{array}{c}0.001 \\
{[0.09]}\end{array}$ & $\begin{array}{c}0.001 \\
{[0.14]}\end{array}$ & $\begin{array}{l}-0.004 \\
{[0.43]}\end{array}$ & $\begin{array}{c}0.004 \\
{[0.62]}\end{array}$ & $\begin{array}{c}0.004 \\
{[0.59]}\end{array}$ & $\begin{array}{c}0.004 \\
{[0.48]}\end{array}$ & $\begin{array}{c}-0.002 \\
{[-0.29]}\end{array}$ \\
\hline Observations & 3679 & 3679 & 2377 & 3679 & 3679 & 2377 & 3679 \\
\hline R-squared & 0.01 & 0.01 & 0.01 & 0.02 & 0.03 & 0.04 & 0.01 \\
\hline Country fixed effects & NO & NO & NO & YES & YES & YES & NO \\
\hline Industry-time fixed effects & YES & YES & YES & YES & YES & YES & YES \\
\hline
\end{tabular}

Robust t statistics in brackets, observations are clustered by country when country fixed effects are omitted, and by country-year in other cases

* significant at $10 \%$; ** significant at $5 \%$; *** significant at $1 \%$

Note: TFP levels relative to leader are expressed in Logs. Regressions are on the full sample (1980-2003), unless indicated 
Table 9. Impact of Labor and Product Market Institutions on ICT Capital Deepening

Dependent variable: annual growth in ICT capital labor ratio

\begin{tabular}{|c|c|c|c|c|c|c|c|c|}
\hline & (1) & $(2)$ & (3) & (4) & (5) & (6) & (7) & (8) \\
\hline ICT capital-labor ratio, relative to leader (t-1) & $\begin{array}{c}0.006 \\
{[4.2]^{* * *}}\end{array}$ & $\begin{array}{c}0.004 \\
{[3.3]^{* * *}}\end{array}$ & $\begin{array}{l}-0.003 \\
{[0.73]}\end{array}$ & $\begin{array}{c}0.004 \\
{[3.31]^{* * *}}\end{array}$ & $\begin{array}{c}0.002 \\
{[2.31]^{* *}}\end{array}$ & $\begin{array}{l}-0.002 \\
{[-1.21]}\end{array}$ & $\begin{array}{l}-0.002 \\
{[-1.49]}\end{array}$ & $\begin{array}{c}0.004 \\
{[1.8]^{*}}\end{array}$ \\
\hline Share of ICT capital in total capital (t-1) & $\begin{array}{c}-0.006 \\
{[-2.92]^{* * *}}\end{array}$ & $\begin{array}{c}-0.008 \\
{[-5.08]^{* * *}}\end{array}$ & $\begin{array}{c}0.003 \\
{[0.69]}\end{array}$ & $\begin{array}{c}-0.009 \\
{[-4.98] * * *}\end{array}$ & $\begin{array}{c}-0.013 \\
{[-8.4]^{* * *}}\end{array}$ & $\begin{array}{c}0.003 \\
{[1.29]}\end{array}$ & $\begin{array}{c}-0.008 \\
{[-3.98]^{* * *}}\end{array}$ & $\begin{array}{c}-0.008 \\
{[-3.35]^{* * *}}\end{array}$ \\
\hline Australia relative to average & & & & & & & & $\begin{array}{l}0.015 \\
{[1.43]}\end{array}$ \\
\hline Sectoral PMR & $\begin{array}{c}-0.038 \\
{[-5.55]^{* * *}}\end{array}$ & & & $\begin{array}{l}-0.009 \\
{[-1.29]}\end{array}$ & $\begin{array}{l}-0.013 \\
{[-1.9]^{*}}\end{array}$ & $\begin{array}{c}0.070 \\
{[3.12]^{* * *}}\end{array}$ & $\begin{array}{c}0.025 \\
{[1.59]}\end{array}$ & \\
\hline EPL & & $\begin{array}{c}-0.022 \\
{[-10.82]^{* * *}}\end{array}$ & & $\begin{array}{c}-0.023 \\
{[-10.39]^{* * *}}\end{array}$ & & $\begin{array}{c}-0.025 \\
{[-11.18]^{* * *}}\end{array}$ & & $\begin{array}{c}-0.021 \\
{[-3.62]^{* * *}}\end{array}$ \\
\hline $\begin{array}{l}\text { EPL } \\
\text { High skill industries }\end{array}$ & & & $\begin{array}{c}-0.021 \\
{[3.47]^{* * *}}\end{array}$ & & & & & \\
\hline $\begin{array}{l}\text { EPL } \\
\text { Low skill industries }\end{array}$ & & & $\begin{array}{c}-0.024 \\
{[3.77]^{* * *}}\end{array}$ & & & & & \\
\hline Observations & 4116 & 4378 & 4378 & 4116 & 4116 & 4116 & 4116 & 4378 \\
\hline R-squared & 0.02 & 0.13 & 0.13 & 0.14 & 0.27 & 0.14 & 0.28 & 0.13 \\
\hline Country fixed effects & NO & NO & NO & NO & YES & NO & YES & NO \\
\hline Industry-time fixed effects & NO & NO & YES & NO & NO & YES & YES & YES \\
\hline
\end{tabular}

Robust t statistics in brackets, observations are clustered by country when country fixed effects are omitted, and by country-year in other cases

* significant at $10 \%$; ** significant at $5 \%$; *** significant at $1 \%$

Note: TFP levels relative to leader are expressed in Logs. Regressions are on the full sample (1980-2003), unless indicated 


\title{
Table 10. Predicted Impact of Product and Labor Market Reforms
}

\author{
Panel A. Predicted impact of product market reforms \\ on MFP growth in Australian ICT using industries
}

\begin{tabular}{lccc}
\hline & Annual MFP growth & PMR (period end) & $\begin{array}{c}\text { Distance to MFP leader } \\
\text { (beg. period) }\end{array}$ \\
\hline $\mathbf{1 9 8 0 - 1 9 9 0}$ & $0.4 \%$ & 0.22 & $42.7 \%$ \\
$\mathbf{1 9 9 1 - 2 0 0 3}$ & $1.2 \%$ & 0.18 & $47.0 \%$ \\
\hline Change in annual MFP : & & Impact of PMR in ICT using \\
Actual & $0.9 \%$ & sectors & Impact of "passive" MFP \\
convergence
\end{tabular}

1/ Predicted change is based on estimates of regression (6) in Table 6.

TFP gaps are averages over 1980-82 and 1991-93 respectively for 1980-1990 and 1991-2003

Note: TFP levels relative to leader are expressed in Logs. Regressions are on the full sample (1980-2003), unless indicated

Panel B. Predicted impact of labor market flexibility on MFP growth in high skill industries across OECD countries

\begin{tabular}{|c|c|c|}
\hline & $\begin{array}{c}\text { Annual MFP growth } \\
(1990-2003)\end{array}$ & EPL index \\
\hline Bottom quartile EPL 1/ & $1.13 \%$ & 0.59 \\
\hline Top quartile EPL 1/ & $0.68 \%$ & 3.61 \\
\hline \multicolumn{3}{|c|}{ Difference in annual MFP growth: } \\
\hline Actual & $0.44 \%$ & . \\
\hline Predicted 2/ & $0.58 \%$ & . \\
\hline
\end{tabular}




\section{Table 11. Controlling for Other Determinants of MFP Growth}

Dependent variable: annual MFP growth

\begin{tabular}{|c|c|c|c|c|c|c|c|}
\hline & (1) & (2) & (3) & (4) & $\begin{array}{c}(5) \\
1990-2003\end{array}$ & (6) & (7) \\
\hline TFP level, relative to leader (t-1) & $\begin{array}{c}-0.00878 \\
{[1.96]^{*}}\end{array}$ & $\begin{array}{l}-0.01983 \\
{[3.97]^{* * *}}\end{array}$ & $\begin{array}{l}-0.02009 \\
{[4.04]^{* * *}}\end{array}$ & $\begin{array}{l}-0.01174 \\
{[3.36]^{* * *}}\end{array}$ & $\begin{array}{c}-0.0043 \\
{[1.02]}\end{array}$ & $\begin{array}{c}-0.01163 \\
{[3.31]^{* * *}}\end{array}$ & $\begin{array}{l}-0.01326 \\
{[2.16]^{* *}}\end{array}$ \\
\hline $\begin{array}{l}\text { TFP level, relative to leader (t-1) } \\
\text { Interacted with PMR in ICT using industries }\end{array}$ & $\begin{array}{c}0.034 \\
{[3.16]^{* * *}}\end{array}$ & $\begin{array}{c}0.028 \\
{[2.59]^{* *}}\end{array}$ & $\begin{array}{c}0.028 \\
{[2.59]^{* *}}\end{array}$ & $\begin{array}{c}0.016 \\
{[2.80]^{* * *}}\end{array}$ & $\begin{array}{c}0.018 \\
{[2.29]^{* *}}\end{array}$ & $\begin{array}{c}0.016 \\
{[2.62]^{* * *}}\end{array}$ & $\begin{array}{c}0.038 \\
{[3.41]^{* * *}}\end{array}$ \\
\hline $\begin{array}{l}\text { TFP level, relative to leader (t-1) } \\
\text { Interacted with PMR in ICT producing industries }\end{array}$ & $\begin{array}{c}0.01773 \\
{[0.85]}\end{array}$ & $\begin{array}{c}0.02833 \\
{[1.35]}\end{array}$ & $\begin{array}{c}0.02974 \\
{[1.43]}\end{array}$ & $\begin{array}{c}-0.00687 \\
{[0.68]}\end{array}$ & $\begin{array}{c}0.00362 \\
{[0.18]}\end{array}$ & $\begin{array}{c}-0.00732 \\
{[0.72]}\end{array}$ & $\begin{array}{l}0.05778 \\
{[1.72]^{*}}\end{array}$ \\
\hline $\begin{array}{l}\text { TFP level, relative to leader (t-1) } \\
\text { Interacted with PMR in other industries }\end{array}$ & $\begin{array}{c}0.00377 \\
{[0.50]}\end{array}$ & $\begin{array}{c}-0.01321 \\
{[1.60]}\end{array}$ & $\begin{array}{c}-0.01366 \\
{[1.67]^{*}}\end{array}$ & $\begin{array}{c}0.00387 \\
{[0.55]}\end{array}$ & $\begin{array}{c}0.00449 \\
{[0.50]}\end{array}$ & $\begin{array}{c}0.00351 \\
{[0.48]}\end{array}$ & $\begin{array}{c}-0.00709 \\
{[0.75]}\end{array}$ \\
\hline EPL in high skill industries & $\begin{array}{c}-0.0019 \\
{[3.37]^{* * *}}\end{array}$ & $\begin{array}{l}-0.0013 \\
{[2.40]^{* *}}\end{array}$ & $\begin{array}{c}-0.0013 \\
{[2.45]^{* *}}\end{array}$ & $\begin{array}{c}-0.0018 \\
{[3.91]^{* * *}}\end{array}$ & $\begin{array}{c}-0.0023 \\
{[4.14]^{* * *}}\end{array}$ & $\begin{array}{c}-0.0018 \\
{[3.94]^{* * *}}\end{array}$ & $\begin{array}{c}-0.0016 \\
{[2.61]^{* *}}\end{array}$ \\
\hline High skill share (t-1) & $\begin{array}{l}0.00042 \\
{[2.30]^{* *}}\end{array}$ & $\begin{array}{c}0.0004 \\
{[2.21]^{* *}}\end{array}$ & $\begin{array}{l}0.00041 \\
{[2.28]^{* *}}\end{array}$ & $\begin{array}{l}0.0002 \\
{[1.45]}\end{array}$ & $\begin{array}{c}0.00046 \\
{[2.85]^{* * *}}\end{array}$ & $\begin{array}{c}0.00019 \\
{[1.45]}\end{array}$ & $\begin{array}{l}0.00053 \\
{[2.55]^{* *}}\end{array}$ \\
\hline R\&D intensity (t-1) & $\begin{array}{l}0.00144 \\
{[2.21]^{* *}}\end{array}$ & $\begin{array}{c}0.00028 \\
{[0.41]}\end{array}$ & & & & & \\
\hline $\begin{array}{l}\text { TFP level, relative to leader (t-1) } \\
\text { Interacted with R\&D intensity }\end{array}$ & & $\begin{array}{c}-0.002 \\
{[5.59]^{* * *}}\end{array}$ & $\begin{array}{c}-0.002 \\
{[6.13]^{* * *}}\end{array}$ & & & & $\begin{array}{c}-0.002 \\
{[4.59]^{* * *}}\end{array}$ \\
\hline Export orientation (t-1) & & & & $\begin{array}{c}0.00105 \\
{[0.81]}\end{array}$ & $\begin{array}{l}0.00268 \\
{[1.72]^{*}}\end{array}$ & $\begin{array}{c}0.00104 \\
{[0.79]}\end{array}$ & $\begin{array}{c}0.00233 \\
{[1.37]}\end{array}$ \\
\hline Trade weighted US R\&D intensity (t-1) & & & & & & $\begin{array}{c}-0.00007 \\
{[0.29]}\end{array}$ & \\
\hline Observations & 2398 & 2398 & 2398 & 3679 & 2377 & 3679 & 1657 \\
\hline R-squared & 0.03 & 0.04 & 0.04 & 0.03 & 0.04 & 0.03 & 0.06 \\
\hline Country fixed effects & $\begin{array}{l}\text { YES } \\
\text { YFS }\end{array}$ & YES & $\begin{array}{l}\text { YES } \\
\text { YFS }\end{array}$ & $\begin{array}{l}\text { YES } \\
\text { YFS }\end{array}$ & YES & YES & $\begin{array}{l}\text { YES } \\
\text { YFS }\end{array}$ \\
\hline
\end{tabular}

Robust t statistics in brackets, observations are clustered by country-year

* significant at $10 \%$; ** significant at $5 \%$; *** significant at $1 \%$

Note: TFP levels relative to leader are expressed in Logs. Regressions are on the full sample (1980-2003), unless indicated 


\section{Appendix I. The Impact of Product and Labor Market Institutions \\ on Labor Productivity}

Dependent variable: annual labor productivity growth

\begin{tabular}{|c|c|c|c|c|c|c|c|c|c|}
\hline & (1) & (2) & (3) & (4) & (5) & $\begin{array}{c}(6) \\
1990-2003 \\
\end{array}$ & (7) & $\begin{array}{c}(8) \\
1990-2003 \\
\end{array}$ & (9) \\
\hline Labor productivity level, relative to leader ( $t-1)$ & $\begin{array}{c}-0.015 \\
{[-5.37]^{* * *}}\end{array}$ & $\begin{array}{l}-0.004 \\
{[1.32]}\end{array}$ & $\begin{array}{c}-0.014 \\
{[5.12]^{* * *}}\end{array}$ & $\begin{array}{c}-0.019 \\
{[-6.28]^{* * *}}\end{array}$ & $\begin{array}{c}-0.019 \\
{[6.27]^{* * *}}\end{array}$ & $\begin{array}{c}-0.017 \\
{[4.09]^{* * *}}\end{array}$ & $\begin{array}{c}-0.018 \\
{[5.52]^{* * *}}\end{array}$ & $\begin{array}{c}-0.016 \\
{[3.93]^{* * *}}\end{array}$ & $\begin{array}{c}-0.018 \\
{[-5.86]^{* * *}}\end{array}$ \\
\hline $\begin{array}{l}\text { Labor productivity level, relative to leader ( } \mathrm{t}-1) \\
\text { Interacted with PMR }\end{array}$ & & & & $\begin{array}{c}0.011 \\
{[2.14]^{* *}}\end{array}$ & & & $\begin{array}{l}0.010 \\
{[1.50]}\end{array}$ & $\begin{array}{l}0.013 \\
{[1.23]}\end{array}$ & \\
\hline $\begin{array}{l}\text { Labor productivity level, relative to leader (t-1) } \\
\text { Interacted with PMR in ICT using industries }\end{array}$ & & & & & $\begin{array}{c}0.029 \\
{[4.41]^{* * *}}\end{array}$ & $\begin{array}{c}\mathbf{0 . 0 2 6} \\
{[3.08]^{* * *}}\end{array}$ & & & $\begin{array}{c}0.029 \\
{[2.76]^{* * *}}\end{array}$ \\
\hline $\begin{array}{l}\text { Labor productivity level, relative to leader }(\mathrm{t}-1) \\
\text { Interacted with PMR in ICT producing industries }\end{array}$ & & & & & $\begin{array}{l}-0.008 \\
{[0.79]}\end{array}$ & $\begin{array}{l}-0.005 \\
{[0.25]}\end{array}$ & & & $\begin{array}{l}-0.010 \\
{[-0.95]}\end{array}$ \\
\hline $\begin{array}{l}\text { Labor productivity level, relative to leader (t-1) } \\
\text { Interacted with PMR in other industries }\end{array}$ & & & & & $\begin{array}{l}0.009 \\
{[1.23]}\end{array}$ & $\begin{array}{l}0.009 \\
{[0.91]}\end{array}$ & & & $\begin{array}{l}0.008 \\
{[0.98]}\end{array}$ \\
\hline $\begin{array}{l}\text { EPL } \\
\text { High skill industries }\end{array}$ & & $\begin{array}{r}-\mathbf{0 . 0 0 2} \\
{[1.47]}\end{array}$ & $\begin{array}{c}-0.002 \\
{[3.62]^{* * *}}\end{array}$ & & & & $\begin{array}{c}-0.002 \\
{[3.16]^{* * *}}\end{array}$ & $\begin{array}{c}-0.002 \\
{[4.63]^{* * *}}\end{array}$ & $\begin{array}{c}-\mathbf{0 . 0 0 2} \\
{[-3.51]^{* * *}}\end{array}$ \\
\hline $\begin{array}{l}\text { EPL } \\
\text { Low skill industries }\end{array}$ & & $\begin{array}{l}0.0006 \\
{[0.48]}\end{array}$ & & & & & & & \\
\hline High skill share (t-1) & $\begin{array}{c}0.0003 \\
{[2.06]^{* *}}\end{array}$ & $\begin{array}{l}0.0002 \\
{[0.93]}\end{array}$ & $\begin{array}{l}0.0004 \\
{[2.12]^{*}}\end{array}$ & $\begin{array}{l}0.0003 \\
{[2.2]^{* *}}\end{array}$ & $\begin{array}{c}0.0004 \\
{[2.49]^{* *}}\end{array}$ & $\begin{array}{c}0.0006 \\
{[3.28]^{* * *}}\end{array}$ & $\begin{array}{c}0.0004 \\
{[1.96]^{*}}\end{array}$ & $\begin{array}{l}0.0006 \\
{[2.26]^{* *}}\end{array}$ & $\begin{array}{c}0.0004 \\
{[2.19]^{* *}}\end{array}$ \\
\hline ICT share $(t-1)$ & $\begin{array}{c}0.015 \\
{[1.98]^{*}}\end{array}$ & $\begin{array}{c}0.013 \\
{[0.97]}\end{array}$ & $\begin{array}{c}0.012 \\
{[0.86]}\end{array}$ & $\begin{array}{c}0.017 \\
{[2.25]^{* *}}\end{array}$ & $\begin{array}{c}0.017 \\
{[2.29]^{* *}}\end{array}$ & $\begin{array}{c}0.024 \\
{[2.51]^{* *}}\end{array}$ & $\begin{array}{c}0.014 \\
{[1.00]}\end{array}$ & $\begin{array}{c}0.023 \\
{[1.80]^{*}}\end{array}$ & $\begin{array}{c}0.014 \\
{[1.14]}\end{array}$ \\
\hline $\begin{array}{l}\text { Observations } \\
\text { R-squared }\end{array}$ & $\begin{array}{l}3942 \\
0.03\end{array}$ & $\begin{array}{l}3942 \\
0.01\end{array}$ & $\begin{array}{l}3942 \\
0.04\end{array}$ & $\begin{array}{l}3724 \\
0.04\end{array}$ & $\begin{array}{l}3724 \\
0.04\end{array}$ & $\begin{array}{l}2397 \\
0.04\end{array}$ & $\begin{array}{l}3724 \\
0.04\end{array}$ & $\begin{array}{l}2397 \\
0.04\end{array}$ & $\begin{array}{l}3724 \\
0.04\end{array}$ \\
\hline $\begin{array}{l}\text { Country fixed effects } \\
\text { Industry-time fixed effects }\end{array}$ & $\begin{array}{l}\text { YES } \\
\text { YES }\end{array}$ & $\begin{array}{l}\text { NO } \\
\text { YES }\end{array}$ & $\begin{array}{l}\text { YES } \\
\text { YES }\end{array}$ & $\begin{array}{l}\text { YES } \\
\text { YES }\end{array}$ & $\begin{array}{l}\text { YES } \\
\text { YES }\end{array}$ & $\begin{array}{l}\text { YES } \\
\text { YES }\end{array}$ & $\begin{array}{l}\text { YES } \\
\text { YES }\end{array}$ & $\begin{array}{l}\text { YES } \\
\text { YES }\end{array}$ & $\begin{array}{l}\text { YES } \\
\text { YES }\end{array}$ \\
\hline
\end{tabular}

Robust t statistics in brackets, observations are clustered by country-year

* significant at $10 \%$; ** significant at $5 \%$; *** significant at $1 \%$

Note: TFP levels relative to leader are expressed in Logs. Regressions are on the full sample (1980-2003), unless indicated 


\section{Appendix II. Dropping Countries One by One}

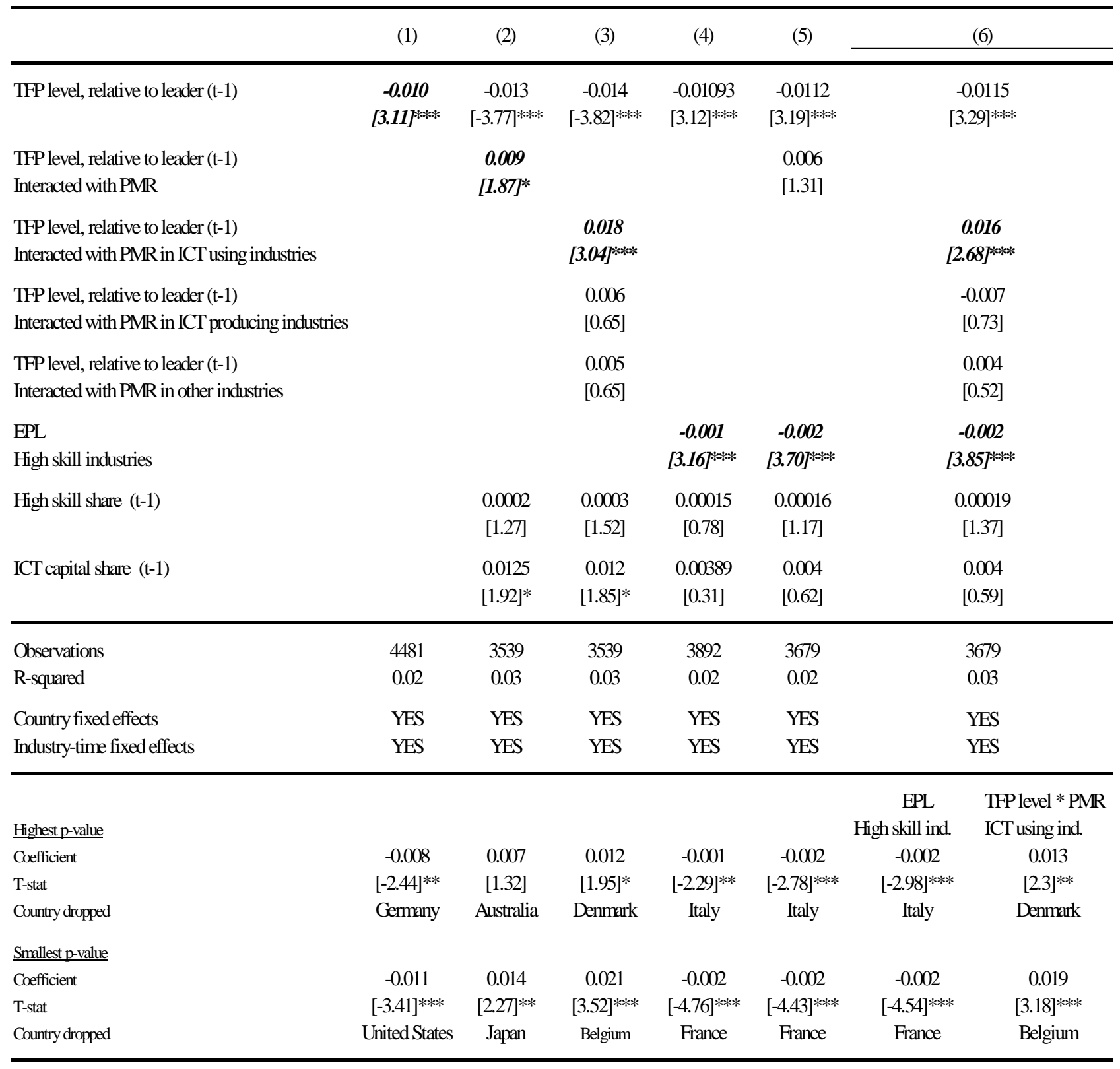

Robust t statistics in brackets, observations are clustered by country-year

* significant at $10 \%$;* significant at $5 \%$; *** significant at $1 \%$

The table reports, for each variable of interest, the coefficient, t statistics, and the country dropped, when the coeficient is the least significant (highest p value) and the most significant (lowest p value).

Note: TFP levels relative to leader are expressed in Logs. Regressions are on the full sample (1980-2003), unless indicated 


\section{Appendix III. Regressions with 3-year Averages}

Dependent variable: 3 years average MFP growth

(overlapping panel)

(1)

(2)

(3)

(6)

(7)

(8)

1990-2003

TFP level, relative to leader ( $\mathrm{t}-2)$

$-0.016$

$-0.017$

$-0.018$

$-0.018$

$-0.018$

$-0.014$

$[4.28]^{* * *}$

$[4.18]^{* * *}$

[4.21]***

[4.30]***

[4.34]***

$[2.85]^{* * *}$

TFP level, relative to leader ( $\mathrm{t}-2)$

0.010

0.009

Interacted with PMR

[1.78]*

[1.57]

Sectoral PMR (t-2)

0.0005

[0.04]

$-0.0012$

$-0.0006 \quad-0.0032$

(0.04)

TFP level, relative to leader ( $t-2)$

Interacted with PMR in ICT using industries

TFP level, relative to leader ( $\mathrm{t}-2)$

Interacted with PMR in ICT producing industries

0.0010

$$
\text { [0.08] }
$$

[0.10]

[0.05]

[0.21]

0.013

$0.014 \quad 0.017$

[1.76]*

[1.79]* $\quad[1.81]^{*}$

0.003

$0.002 \quad-0.010$

[0.21]

[0.12] [0.54]

TFP level, relative to leader ( $\mathrm{t}-2$ )

$\begin{array}{lll}0.009 & 0.008 & 0.010\end{array}$

Interacted with PMR in other industries

[1.59]

[1.27] [1.30]

EPL

High skill industries

$\begin{array}{lll}-0.0016 & -0.0017 & -0.0018\end{array}$

$[2.98]^{* * *} \quad[3.02]^{* * *} \quad[2.52]^{* *}$

\begin{tabular}{lcccccc}
\hline Observations & 4255 & 4002 & 4002 & 4002 & 4002 & 2607 \\
R-squared & 0.05 & 0.05 & 0.05 & 0.05 & 0.05 & 0.07 \\
Country fixed effects & YES & YES & YES & YES & YES & YES \\
Industry-time fixed effects & YES & YES & YES & YES & YES & YES \\
\hline
\end{tabular}

Dependent variable is the 3-year moving average growth rate of MFP growth (years $t+1$, $t$ and $t-1$ )

Robust t statistics in brackets, observations are clustered by country-industry

* significant at 10\%; ** significant at 5\%; *** significant at $1 \%$

Note: TFP levels relative to leader are expressed in Logs. Regressions are on the full sample (1980-2003), unless indicated 